\title{
3-Nitrooxypropanol decreases methane emissions and increases hydrogen emissions of early lactation dairy cows, with associated changes in nutrient digestibility and energy metabolism
}

\author{
Sanne van Gastelen, ${ }^{1 *} \odot$ Jan Dijkstra, ${ }^{2} \odot$ Gisabeth Binnendijk, ${ }^{1}$ Stéphane M. Duval, ${ }^{3}$ Jeroen M. L. Heck, ${ }^{4} \odot$ \\ Maik Kindermann, ${ }^{3}$ Tamme Zandstra, ${ }^{2}$ and André Bannink ${ }^{1}$ \\ ${ }^{1}$ Wageningen Livestock Research, Wageningen University \& Research, PO Box 338, $6700 \mathrm{AH}$, Wageningen, the Netherlands \\ ${ }^{2}$ Animal Nutrition Group, Wageningen University \& Research, PO Box 338, $6700 \mathrm{AH}$, Wageningen, the Netherlands \\ ${ }^{3}$ DSM Nutritional Products, Animal Nutrition and Health, PO Box 2676, 4002 Basel, Switzerland \\ ${ }^{4}$ Friesland Campina, PO Box 1551, 3800 BN, Amersfoort, the Netherlands
}

\begin{abstract}
The aim of this study was to determine the methane $\left(\mathrm{CH}_{4}\right)$ mitigation potential of 3-nitrooxypropanol and the persistency of its effect when fed to dairy cows in early lactation. Sixteen Holstein-Friesian cows (all multiparous; 11 cows in their second parity and 5 cows in their third parity) were blocked in pairs, based on actual calving date, parity, and previous lactation milk yield, and randomly allocated to 1 of 2 dietary treatments: a diet including $51 \mathrm{mg}$ of 3-nitrooxypropanol $/ \mathrm{kg}$ of dry matter (3-NOP) and a diet including a placebo at the same concentration $(\mathrm{CON})$. Cows were fed a $35 \%$ grass silage, $25 \%$ corn silage, and $40 \%$ concentrate (on dry matter basis) diet from $3 \mathrm{~d}$ after calving up to $115 \mathrm{~d}$ in milk (DIM). Every 4 weeks, the cows were housed in climate respiration chambers for $5 \mathrm{~d}$ to measure lactation performance, feed and nutrient intake, apparent total-tract digestibility of nutrients, energy and $\mathrm{N}$ metabolism, and gaseous exchange (4 chamber visits per cow in total, representing 27, 55, 83, and 111 DIM). Feeding 3-NOP did not affect dry matter intake (DMI), milk yield, milk component yield, or feed efficiency. These variables were affected by stage of lactation, following the expected pattern of advanced lactation. Feeding 3-NOP did not affect $\mathrm{CH}_{4}$ production $(\mathrm{g} / \mathrm{d})$ at 27 and 83 DIM, but decreased $\mathrm{CH}_{4}$ production at 55 and 111 DIM by an average of $18.5 \%$. This response in $\mathrm{CH}_{4}$ production is most likely due to the differences observed in feed intake across the different stages of lactation because $\mathrm{CH}_{4}$ yield $(\mathrm{g} /$ $\mathrm{kg}$ of DMI) was lower (on average 16\%) at each stage of lactation upon feeding 3-NOP. On average, feeding 3 -NOP increased $\mathrm{H}_{2}$ production and intensity 12-fold;
\end{abstract}

Received November 20, 2019

Accepted April 10, 2020.

*Corresponding author: sanne.vangastelen@wur.nl with the control diet, $\mathrm{H}_{2}$ yield did not differ between the different stages of lactation, whereas with the 3-NOP treatment $\mathrm{H}_{2}$ yield decreased from $0.429 \mathrm{~g} / \mathrm{kg}$ of DMI at 27 DIM to $0.387 \mathrm{~g} / \mathrm{kg}$ of DMI at 111 DIM. The apparent total-tract digestibility of dry matter, organic matter, neutral detergent fiber, and gross energy was greater for the 3-NOP treatment. In comparison to the control treatment, 3-NOP did not affect energy and $\mathrm{N}$ balance, except for a greater metabolizable energy intake to gross energy intake ratio (65.4 and $63.7 \%$, respectively) and a greater body weight gain (average 0.90 and $0.01 \%$ body weight change, respectively). In conclusion, feeding 3-NOP is an effective strategy to decrease $\mathrm{CH}_{4}$ emissions (while increasing $\mathrm{H}_{2}$ emission) in early lactation Holstein-Friesian cows with positive effects on apparent total-tract digestibility of nutrients. Key words: dairy cow, 3-nitrooxypropanol, lactation stage, enteric methane production

\section{INTRODUCTION}

Enteric $\mathrm{CH}_{4}$ is a natural end product of microbial fermentation of feed in the rumen and hindgut of ruminant livestock. Although methanogens play an essential role in the removal of $\mathrm{H}_{2}$ from the rumen to prevent inhibition of microbial metabolism (McAllister and Newbold, 2008), $\mathrm{CH}_{4}$ has no nutritional value for the animal and is released into the atmosphere mainly through eructation and breath. Because $\mathrm{CH}_{4}$ is a potent greenhouse gas that contributes to global warming, enteric $\mathrm{CH}_{4}$ production has become one of the main targets of greenhouse gas mitigation practices for the dairy industry (Hristov et al., 2013).

Comprehensive reviews on enteric $\mathrm{CH}_{4}$ mitigation strategies have been published (e.g., Beauchemin et al., 2008; Martin et al., 2010; Hristov et al., 2013). Several dietary strategies have been proposed to mitigate enteric $\mathrm{CH}_{4}$ production, including the use of feed additives. Some feed additives are inhibitors of methanogenesis, 
natural or synthetic compounds that directly inhibit methanogenesis by rumen archaea. Recently, Duin et al. (2016) described the characteristics of the feed additive 3-nitrooxypropanol (3-NOP).

The compound $3-\mathrm{NOP}$ is a highly specific inhibitor that targets the nickel enzyme methyl-coenzyme $\mathrm{M}$ reductase, which catalyzes the final step in methanogenesis in rumen archaea (Duin et al., 2016). At low concentrations, 3-NOP appears to inhibit methanogens without having a negative effect on performance in dairy cattle (Hristov et al., 2015; Lopes et al., 2016; Haisan et al., 2014; 2017). Hence, 3-NOP seems to be an effective feed additive to mitigate $\mathrm{CH}_{4}$ emission of dairy cows. Melgar et al. (2020) investigated the effect of 3-NOP fed to dairy cattle on a corn silage-based diet throughout the entire early lactation period, starting from onset of lactation until 105 DIM. In that study, emissions of both $\mathrm{CH}_{4}$ and $\mathrm{H}_{2}$ were measured with the GreenFeed system. Neither the persistency of the effect of 3-NOP nor effects of 3-NOP on energy balance were reported by Melgar et al. (2020). Therefore, the aim of this study was to determine the $\mathrm{CH}_{4}$ mitigation potential of 3-NOP and its persistency in postpartum dairy cows, as well as the effects on feed intake, energy and $\mathrm{N}$ balance, milk production and composition, milk fatty acid profile, and $\mathrm{H}_{2}$ emissions.

\section{MATERIALS AND METHODS}

\section{Experimental Design}

The experiment was conducted from February until July 2017 at the animal research facilities of Wageningen University \& Research (Wageningen, the Netherlands), under the Dutch law on Animal Experiments in accordance with European Union Directive 2010/63, and approved by the Central Committee of Animal Experiments (The Hague, the Netherlands; 2016.D0060.001). The use of 3 -NOP (10\%) in 1,2-propanediol on silicon dioxide (DSM Nutritional Products Ltd., Basel, Switzerland) in animal feed was preapproved by the Veterinary Drugs Directorate Division (Utrecht, the Netherlands). Milk was discarded during the study and upon completion a 7 -d withdrawal period was implemented.

The experiment followed a completely randomized block design with 2 dietary treatments and 16 HolsteinFriesian dairy cows. All cows were multiparous; 11 cows were in their second parity and 5 cows in their third parity (i.e., 3 assigned to the control treatment and 2 assigned to the 3-NOP supplemented treatment). Cows were blocked in pairs based on actual calving date, parity $(2.4 \pm 0.52$ for control treatment and $2.3 \pm 0.46$ for 3 -NOP treatment; mean \pm standard deviation; SD), and previous lactation milk yield ( $\mathrm{kg}$ of milk per 305-d lactation; 8,599 \pm 580 for control treatment and 8,405 \pm 714 for 3 -NOP treatment; mean \pm SD). Subsequently, cows within a block were randomly assigned to 1 of the 2 dietary treatments: a control diet with silicon dioxide (CON) and a diet with 3-NOP on silicon dioxide (3NOP). The dairy cows received the experimental diets from $3 \mathrm{~d}$ after calving up to approximately 115 DIM.

Three weeks before their expected calving dates, the cows were transferred from the freestall barn to a tiestall barn. These 3 wk were considered to be the closeup period, during which the cows were fed a transition diet according to standard operating procedures at the experimental facilities (i.e., a mixture of grass silage, corn silage, hay, and water). Approximately $1 \mathrm{wk}$ before the expected calving date, the dairy cows were switched to a diet comprising $50 \%$ of the transition diet and $50 \%$ of the lactation diet on an ingredient basis (i.e., experimental diet without supplement). On the third day after calving, the cows were switched to the CON or 3-NOP treatment.

After calving, the cows were housed in the tie-stalls for another $3 \mathrm{wk}$, during which DMI and milk yield were recorded, before they were transferred to the climate respiration chambers (CRC) for their first 5-d measurement period. This schedule (i.e., $3 \mathrm{wk}$ in the tie-stall barn and 1 wk with $5 \mathrm{~d}$ in the CRC) was repeated 4 times, resulting in 4 measurement periods in the CRC per cow at 27, 55, 83, and $111 \pm 3.1 \mathrm{DIM}$ (average $\pm \mathrm{SD}$; similar SD for all). Four identical, individual chambers were available, and groups of 4 cows ( 2 blocks of 2 cows each) were allocated to the chambers in a staggered manner.

\section{Diets, Feeding, and Housing}

Both the CON and the 3-NOP treatment consisted of $35 \%$ grass silage, $25 \%$ corn silage, and $40 \%$ concentrate mixture, on a DM basis. The ingredient and chemical composition of both treatments are presented in Table 1. To determine apparent total-tract nutrient digestibility, $\mathrm{TiO}_{2}$ was included in the concentrate of both treatments as an external marker. The concentrate was in meal form and produced by Research Diet Services (RDS BV, Wijk bij Duurstede, the Netherlands) in a single batch, and hence was assumed to be of uniform composition throughout the experiment. Diets were formulated to meet the requirements for maintenance and milk production of dairy cows in early lactation. The $\mathrm{NE}_{\mathrm{L}}$ was calculated with the Dutch $\mathrm{NE}_{\mathrm{L}}$ system (VEM as feed unit lactation; Van Es, 1978), and the Dutch protein evaluation system DVE/OEB 2010 (DVE as intestinal digestible protein and OEB as rumen degradable protein balance; Van Duinkerken et al., 2011). 
The supplement (silicon dioxide $+1,2$ propanediol only as placebo supplement for the CON treatment; $10 \% 3$-NOP on silicon dioxide $+1,2$-propanediol as supplement for the 3-NOP treatment) was first mixed with ground corn, soybean oil, and wet molasses $(10 \%$ supplement, $68 \%$ ground corn, $6 \%$ soybean oil, and $16 \%$ wet molasses on wt/wt basis). This mixture was subsequently mixed with the concentrate using a Forberg F60 Paddle-shift mixer (Halvor Forberg A/S, Oslo, Norway) resulting in the concentrate mixture (Table 1) and stored at $6^{\circ} \mathrm{C}$. This procedure was performed 3 times weekly. Daily, the concentrate mixture was mixed with grass silage, corn silage, and water to compose a TMR using a self-propelled mixer wagon (Strautmann Verti-Mix 500, Bad Laer, Germany) equipped with a cutter loader system and an electronic weighing scale, and subsequently stored at $6^{\circ} \mathrm{C}$ if not fed directly after preparation. The 3-NOP TMR was always prepared after preparation of the CON TMR was finished. The target inclusion level was $60 \mathrm{mg}$ of $3-\mathrm{NOP} / \mathrm{kg}$ of $\mathrm{DM}$ for the 3-NOP TMR.

Cows were fed individually and milked twice daily at $0530 \mathrm{~h}$ and $1530 \mathrm{~h}$ throughout the experiment in the tie-stall barn, as well as in the CRC. The daily amount of TMR consumed by each individual cow was calculated from the amounts of feed fed in the morn- ing and afternoon of the previous day and the refusals present in the feed bunk before the morning feeding. Cows were fed ad libitum, allowing $10 \%$ refusals. Cows had free access to clean drinking water throughout the experiment.

On Monday afternoon (1300 h) of every fourth week (i.e., after 3 wk in the tie-stall barn), the cows were individually transported to 1 of 4 identical CRC (i.e., each cow was housed in another CRC during each measurement period) for a 5 -d measurement period to determine cow performance, gaseous exchange, energy and $\mathrm{N}$ balance, and apparent total-tract nutrient digestibility.

\section{Climate Respiration Chambers}

A detailed description of the CRC design and gas measurements is reported by Heetkamp et al. (2015) and van Gastelen et al. (2015). Briefly, the relative humidity and temperature of each CRC (i.e., an area of $11.8 \mathrm{~m}^{2}$ and a volume of $34.5 \mathrm{~m}^{3}$ ) was maintained at $65 \%$ and $16^{\circ} \mathrm{C}$, respectively. The CRC were equipped with thin walls with windows to allow audio-visual contact, minimizing the effect of social isolation on cow behavior and performance. Cows were exposed to 16 $\mathrm{h}$ of light per day (0530 to $2130 \mathrm{~h}$ ) and housed in the

Table 1. Chemical composition ( $\mathrm{g} / \mathrm{kg}$ of DM, unless otherwise stated) of the TMR ingredients (analyzed) and of the complete TMR (calculated) ${ }^{1}$

\begin{tabular}{|c|c|c|c|c|c|c|c|c|c|c|}
\hline \multirow[b]{2}{*}{ Item } & \multirow{2}{*}{$\begin{array}{l}\text { Grass } \\
\text { silage }^{2}\end{array}$} & \multirow{2}{*}{$\begin{array}{l}\text { Corn } \\
\text { silage }^{3}\end{array}$} & \multicolumn{2}{|c|}{$\begin{array}{l}\text { Concentrate } \\
\text { mixture }\end{array}$} & \multicolumn{6}{|c|}{ TMR } \\
\hline & & & $\mathrm{CON}$ & $3-\mathrm{NOP}$ & $\mathrm{CON}^{5}$ & $3-\mathrm{NOP}^{5}$ & $27 \mathrm{DIM}^{6}$ & $55 \mathrm{DIM}^{6}$ & $83 \mathrm{DIM}^{6}$ & $111 \mathrm{DIM}^{6}$ \\
\hline $\mathrm{OM}$ & 917 & 963 & 920 & 921 & 930 & 930 & 930 & 929 & 929 & 931 \\
\hline $\mathrm{CP}$ & 189 & 79 & 219 & 219 & 174 & 174 & 171 & 173 & 175 & 177 \\
\hline Crude fat & 40 & 30 & 37 & 37 & 36 & 36 & 35 & 35 & 37 & 38 \\
\hline $\mathrm{ADF}$ & 277 & 218 & 140 & 145 & 207 & 209 & 205 & 209 & 209 & 210 \\
\hline $\mathrm{ADL}$ & 9.5 & 11.6 & 1.5 & 1.7 & 6.8 & 6.9 & 6.5 & 6.8 & 7.1 & 7.1 \\
\hline Starch & $-^{7}$ & 334 & 235 & 231 & 178 & 176 & 179 & 174 & 179 & 176 \\
\hline Sugar & 79 & - & 92 & 92 & 64 & 65 & 64 & 65 & 64 & 66 \\
\hline
\end{tabular}

${ }^{1}$ The TMR was composed of $31 \%$ grass silage, $33 \%$ corn silage, $20 \%$ concentrate mixture, and $16 \%$ water on product basis, which equals 350 g/ $\mathrm{kg}$ of DM grass silage, $250 \mathrm{~g} / \mathrm{kg}$ of DM corn silage, and $400 \mathrm{~g} / \mathrm{kg}$ of DM concentrate mixture.

${ }^{2} \mathrm{NE}_{\mathrm{L}}$ (van Es, 1978) =6.8 MJ/kg of DM; intestinal digestible protein (DVE; van Duinkerken et al., 2011) = 70 g/kg of DM; rumen degraded protein balance (OEB; van Duinkerken et al., 2011) $=35 \mathrm{~g} / \mathrm{kg}$ of DM; ensiling characteristics: acetic acid $=5 \mathrm{~g} / \mathrm{kg}$ of DM, lactic acid $=3 \mathrm{~g} /$ $\mathrm{kg}$ of $\mathrm{DM}$, ammonia- $\mathrm{N}=2.6 \%$ total $\mathrm{N}$, and $\mathrm{pH}=6.0$.

${ }^{3} \mathrm{NE}_{\mathrm{L}}=7.0 \mathrm{MJ} / \mathrm{kg}$ of DM; intestinal digestible protein $(\mathrm{DVE})=55 \mathrm{~g} / \mathrm{kg}$ of DM; rumen degraded protein balance $(\mathrm{OEB})=-45 \mathrm{~g} / \mathrm{kg}$ of DM; ensiling characteristics: acetic acid $=9 \mathrm{~g} / \mathrm{kg}$ of DM, lactic acid $=56 \mathrm{~g} / \mathrm{kg}$ of DM, ammonia- $\mathrm{N}=10.3 \%$ total $\mathrm{N}$, and $\mathrm{pH}=3.9$.

${ }^{4}$ The concentrate mixture consisted of $987.1 \mathrm{~g} / \mathrm{kg}$ of DM concentrate, $8.9 \mathrm{~g} / \mathrm{kg}$ of DM ground corn, $0.9 \mathrm{~g} / \mathrm{kg}$ of DM soybean oil, $1.8 \mathrm{~g} / \mathrm{kg}$ of DM molasses, and $1.3 \mathrm{~g} / \mathrm{kg}$ of supplement (i.e., placebo supplement for CON diet and 3-NOP supplement for 3-NOP diet). Concentrate added to the concentrate mixture contained $(\mathrm{g} / \mathrm{kg}$ of $\mathrm{DM})$ : $\operatorname{corn}=310$, soybean meal $=160$, rumen-protected soybean meal (MervoBest, Nuscience, Utrecht, the Netherlands $)=150$, soybean hulls $=200$, sugar beet pulp $=100$, molasses $=40$, soybean oil $=7.5, \mathrm{CaCO} 3=14, \mathrm{NaCl}=5.0, \mathrm{MgO}=0.5$, trace mineral and vitamin $\operatorname{mix}=8.0$, and $\mathrm{TiO}_{2}=5.0 . \mathrm{CON}=$ control diet; 3 -NOP $=$ diet with 3-nitrooxypropanol as additive.

${ }^{5}$ Calculated TMR composition for CON and 3-NOP treatments, averaged over 27, 55, 83, and 111 DIM.

${ }^{6}$ Calculated TMR composition for 27, 55, 83, and 111 DIM, averaged over the CON and 3-NOP treatments.

${ }^{7}$ Not determined. 
CRC until Friday morning (0900 h) when they returned to the tie-stall barn.

A $\mathrm{H}_{2}$ analyzer (type MGA 3000 multi gas analyzer, ADC Gas Analysis Ltd., Hoddesdon, UK) was installed in series with the $\mathrm{O}_{2}, \mathrm{CO}_{2}$, and $\mathrm{CH}_{4}$ gas analyzers. Inlet and exhaust air of each CRC was sampled with an average interval of $12.5 \mathrm{~min}$ (i.e., four 12-min intervals for each CRC and one 15-min interval for inlet air), similar to the study described by van Gastelen et al. (2017). Production of $\mathrm{CO}_{2}, \mathrm{H}_{2}$, and $\mathrm{CH}_{4}$ and consumption of $\mathrm{O}_{2}$ was calculated from the difference between inlet and exhaust gas volumes. The ventilation rate within the CRC was $58 \mathrm{~m}^{3} / \mathrm{h}$ to ensure that the peaks in $\mathrm{H}_{2}$ concentration after feeding were captured and fell within the optimum range required for the $\mathrm{H}_{2}$ analyzer $(0-100$ $\mathrm{ppm})$. Staff entered the CRC for approximately $30 \mathrm{~min}$ twice daily at $0530 \mathrm{~h}$ and $1530 \mathrm{~h}$ for feeding (i.e., clearing of feed-orts and refeeding) and milking. Similar to a previous study (van Gastelen et al., 2017), we decided not to discard the gas measurements during feeding and milking to capture the $\mathrm{H}_{2}$ concentration peak that occurs directly after feeding when staff are still in the CRC. Van Gastelen et al. (2017) demonstrated that including this period of data collection did not affect the daily production of $\mathrm{CH}_{4}$.

Gas concentrations and ventilation rates were corrected for pressure, temperature, and relative humidity to obtain standard temperature pressure dew point volumes of inlet and exhaust air. Once a day, calibration gases were sampled for gas analysis instead of the inlet air, and the analyzed and actual values of these calibration gases were used to correct the measured gas concentrations from the inlet air and exhaust air of all CRC. Before the experiment started and after the experiment finished, each CRC was checked by releasing known amounts of $\mathrm{CO}_{2}, \mathrm{CH}_{4}$, and $\mathrm{H}_{2}$ (the latter 2 only after the experiment finished), and comparing these values with the data from the gas analysis system to determine recovery. The average recovery of $\mathrm{CO}_{2}$ was $99.2 \%$ (for individual chambers between 98.3 and $100.2 \%$ ), the average recovery of $\mathrm{CH}_{4}$ was $99.6 \%$ (between 96.6 and $101.3 \%$ ), and the average recovery of $\mathrm{H}_{2}$ was $95.6 \%$ (between 93.8 and $97.4 \%$ ).

\section{Sample Collection and Measurements}

Samples of grass silage, corn silage, and both concentrate mixtures were obtained every Monday when fresh feed was prepared. These samples were subsequently pooled per measurement period, subsampled, and stored at $-20^{\circ} \mathrm{C}$ until analysis. During the 5 -d period in the CRC, feed residues were collected twice daily (0530 $\mathrm{h}$ and $1530 \mathrm{~h}$ ), weighed, and stored at $4^{\circ} \mathrm{C}$. At the end of the 5-d period in the CRC, daily orts were pooled per cow, mixed, subsampled, and stored at $-20^{\circ} \mathrm{C}$ until analysis.

While the cows were housed in the CRC, milk yield was recorded and milk was collected at each milking (i.e., twice daily at $0530 \mathrm{~h}$ and $1530 \mathrm{~h}$ ). A milk sample $(10-\mathrm{mL})$ of each milking event was collected in a tube containing sodium azide $(5-\mu \mathrm{L})$ for preservation, stored no longer than $4 \mathrm{~d}$ at $4^{\circ} \mathrm{C}$, and analyzed for fat, protein, lactose, and urea content. Average daily milk composition was calculated from milk composition and milk yield of both daily milking events. The average of individual daily milk compositions, milk yields, and DMI in each CRC measurement period was used for statistical analysis. An additional milk sample (5 g/ $\mathrm{kg}$ of milk) was collected at each milking event in the CRC, pooled per cow for every measurement period in the CRC, and stored at $-20^{\circ} \mathrm{C}$ until milk energy and $\mathrm{N}$ analyses. For milk fatty acid (MFA) composition, milk samples were collected according to van Gastelen et al. (2015), pooled per cow per period, and stored at $-20^{\circ} \mathrm{C}$ until analysis.

Measurements of $\mathrm{CH}_{4}, \mathrm{H}_{2}$, and $\mathrm{CO}_{2}$ production, and $\mathrm{O}_{2}$ consumption were based on data recorded from $0800 \mathrm{~h}$ on the second day in the CRC through 0800 $\mathrm{h}$ on the fifth day in the CRC. Cows were weighed when entering and leaving the CRC. The feces and urine produced during the 5 -d period in the CRC were quantitatively collected (by cleaning the entire CRC), weighed, mixed, subsampled $(0.9 \pm 0.14 \%$ relative to total amount; mean $\pm \mathrm{SD}$ ), and stored at $-20^{\circ} \mathrm{C}$ until analysis, similar to van Gastelen et al. (2015). In addition, samples of condensed water (i.e., collected from the heat exchanger) and of $25 \%$ sulfuric acid solution (wt/wt; through which aerial ammonia in outflowing air was trapped) of each CRC were collected to account for $\mathrm{N}$ volatilized in the form of ammonia from the mix of feces and urine collected during the entire measurement period when cows were in the CRC. During the $5 \mathrm{~d}$ in the CRC, rectal grab samples $(\sim 300 \mathrm{~g})$ were collected twice daily at $0530 \mathrm{~h}$ and $1530 \mathrm{~h}$ and stored at $-20^{\circ} \mathrm{C}$ until analysis. Before analysis, the grab samples were thawed, pooled per cow and measurement period, mixed, and subsampled for analysis.

\section{Chemical Analysis}

Samples of feed, feed residues, manure, and the rectal grab samples were thawed at room temperature, oven-dried at $60^{\circ} \mathrm{C}$, ground to pass a 1-mm screen using a cross beater mill for both silages (Peppink 100AN, Olst, the Netherlands) and an ultra-centrifugal mill for all other samples (Retsch ZM200, Retsch GmbH, Haan, 
Germany), and analyzed by wet chemistry [DM, ash, $\mathrm{N}$, starch, reducing sugars (i.e., all carbohydrates with reducing properties and soluble in $40 \%$ ethanol), crude fat, NDF, ADF, and ADL] as described by Abrahamse et al. (2008). Bomb calorimetry (ISO 9831; International Organization for Standardization, 1998) was used to determine gross energy (GE). Crude protein was calculated as $\mathrm{N} \times 6.25$, where $\mathrm{N}$ was determined using the Kjeldahl method with $\mathrm{CuSO}_{4}$ as a catalyst (ISO 5983; International Organization for Standardization, 2005). The $\mathrm{N}$ concentrations in manure and roughages were determined in fresh material according to Klop et al. (2016).

Grass silage, corn silage, and concentrates were analyzed for DM, ash, N, crude fat, starch (except for grass silage), reducing sugars (except for corn silage), NDF, ADF, ADL, and GE. Feed residues were analyzed for DM and ash. Manure samples were analyzed for DM, $\mathrm{N}$, and GE. The rectal grab samples were analyzed for DM, ash, N, crude fat, starch, NDF, and GE. The $\mathrm{TiO}_{2}$ content of the concentrate mixtures, as well as the rectal grab samples, was determined using the procedure described by Nichols et al. (2018).

Milk samples from individual milking events were analyzed for fat, protein, lactose, and urea content by midinfrared spectroscopy (ISO 9622; International Organization for Standardization, 2013; VVB, Doetinchem, the Netherlands). Pooled milk samples were analyzed for GE and N content according to methods described by Hatew et al. (2015). Fat- and protein-corrected milk yield (FPCM) was calculated according to the equation $\mathrm{FPCM}(\mathrm{kg} / \mathrm{d})=(0.337+0.116 \times$ fat $\%+$ $0.06 \times$ protein \%) $\times$ milk yield $(\mathrm{kg} / \mathrm{d})(\mathrm{CVB}, 2012)$. Energy-corrected milk was calculated according to the equation $\mathrm{ECM}(\mathrm{kg} / \mathrm{d})=$ [milk yield $(\mathrm{kg} / \mathrm{d}) \times 0.327$ ] $+[$ fat yield $(\mathrm{kg} / \mathrm{d}) \times 12.95]+[$ protein yield $(\mathrm{kg} / \mathrm{d}) \times$ 7.25] (Tyrrell and Reid, 1965). The MFA composition of the pooled milk samples was determined using GC (Thermo Electron Corp., Waltham, MA) by Qlip (Qlip B.V., Zutphen, the Netherlands) with a split/splitless injector and $\mathrm{H}_{2}$ as carrier gas as described by van Gastelen et al. (2015).

Samples of the CON and 3-NOP TMR were collected weekly throughout the study, frozen at $-20^{\circ} \mathrm{C}$, and transported to DSM Nutritional Products (Kaiseraugst, Switzerland) on dry ice at the end of the study for analysis of 3-NOP content. Upon arrival, the samples were thawed, weighed, and extracted with acetonitrile containing $0.5 \%$ formic acid at $50^{\circ} \mathrm{C}$ in a sonication bath. An aliquot (2-mL) was centrifuged at 13,148 $\times$ $g$ in an Eppendorf bench-top centrifuge and the clear supernatant analyzed via an Agilent HPLC-UV system (Agilent 1200, Agilent Technologies AG, Basel, Swit- zerland) equipped with a RP-18 column (Accucore Polar Premium, $150 \times 4.6 \mathrm{~mm}, 2.6 \mu \mathrm{m}$, Thermo) at 210 $\mathrm{nm}$. The following gradients, consisting of mobile phase A [water/acetonitrile/methane sulfonic acid (95/5/0.1, $\mathrm{vol} / \mathrm{vol} / \mathrm{vol}$ )] and $\mathrm{B}$ [water/acetonitrile/methane sulfonic acid $(80 / 20 / 0.1, \mathrm{vol} / \mathrm{vol} / \mathrm{vol})]$, were applied with a flow of $0.4 \mathrm{~mL} / \mathrm{min}: 100 \%$ A 0 to $10.5 \mathrm{~min}$ at $100 \%$ A, to $100 \% \mathrm{~B}$ within $0.5 \mathrm{~min}(10.5 \mathrm{~min})$, staying at $100 \% \mathrm{~B}$ for $5.5 \mathrm{~min}$ (16 min), returning to $100 \% \mathrm{~A}$ within $0.5 \mathrm{~min}$ (16.5 $\mathrm{min}$ ) and equilibrating at $100 \% \mathrm{~A}$ until run time end (25 min). Quantification was done by applying the standard addition technique as follows: different quantities of 3-NOP solution were added to blank TMR and the calibration samples extracted in a similar manner to the unknown samples. The obtained analytical result was converted to dry weight basis by correcting for the DM content of the original sample.

\section{Statistical Analysis}

One animal (CON treatment) was removed from the experiment just before the second measurement in the CRC because of an accident. A single measurement of 2 more animals (the first measurement in the CRC of a CON treatment cow and the fourth measurement in the CRC of a 3-NOP treatment cow) were removed from statistical analyses due to general health issues unrelated to the dietary treatments or experimental conditions or because of outlying values $(>3 \times \mathrm{SD})$ for milk yield and $\mathrm{CH}_{4}$ emission.

All variables related to feed intake, milk production, and milk composition while cows were housed in the CRC were averaged per cow per measurement period. The variables related to energy and $\mathrm{N}$ balance were expressed per kilogram of metabolic BW $\left(\mathbf{B W}^{0.75}\right)$ per day. Cow was considered the experimental unit for all variables. Data were analyzed using the MIXED procedure in SAS (version 9.3, SAS Institute Inc., Cary, NC, USA). Dietary treatment (i.e., CON and 3-NOP), DIM (i.e., 27, 55, 83, and 111 DIM), and their interaction were considered fixed effects. For all analyses, the fixed effect of CRC was initially included in the model, but was removed because it tended to affect only 3 response variables (i.e., $0.05<P<0.10$; equally distributed over the different variable categories) and was found to be not significant (i.e., $P>0.10$ ) for the remainder of the variables. The model included block and cow as random factor, and the data were subjected to repeated measures ANOVA to account for repeated measurements with the same cow. The covariance structure autoregressive 1 was used, as it had the lowest overall Akaike's information criterion values, and the Kenward-Roger option was used to estimate the 
denominator degrees of freedom. Differences between treatment means were compared using the least squares means procedure and the Tukey-Kramer method for multiple comparisons when an effect of DIM or an interaction was detected at $P \leq 0.05$. All results are reported as least squares means, representing the CON and 3-NOP treatments (averaged over 27, 55, 83, and 111 DIM) or DIM (averaged over the CON and 3-NOP treatments) with significance of effects declared at $P \leq$ 0.05 and tendencies at $0.05<P \leq 0.10$.

\section{RESULTS}

\section{Nutrient Intake and Digestibility}

The average 3 -NOP recovery was $86.8 \%$, which is equivalent to an inclusion level of $51 \mathrm{mg} / \mathrm{kg}$ of DM. Nutrient intake, DMI, and apparent total-tract digestibility of nutrients were not affected by treatment $x$ DIM interactions. Nutrient intake and DMI were also not affected by $3-\mathrm{NOP}$, but the apparent total-tract digestibility of DM, OM, GE, and NDF were higher $(P$ $\leq 0.042$; Table 2), and the apparent total-tract digestibility of $\mathrm{CP}$ tended to be higher $(P=0.059)$ for the 3 -NOP treatment compared with the CON treatment. Days in milk affected DMI and the intake of all nutrients $(P<0.001)$, which were generally lower for 27 DIM compared with 55, 83, and 111 DIM. The appar- ent total-tract digestibility of DM, OM, and GE were lower $(P \leq 0.039)$ at 83 DIM compared with 27 DIM, and the apparent total-tract digestibility of $\mathrm{CP}$ was lower $(P=0.008)$ at 83 DIM compared with 55 DIM.

\section{Lactation Performance}

Only feed efficiency ( $\mathrm{kg}$ of FPCM/kg of DMI) tended to be affected by a treatment $\times$ DIM interaction $(P$ $=0.081$; Table 3). Milk fat content and milk protein content were higher for the 3 -NOP treatment compared with the CON treatment $(P=0.022$ and $P=0.031$, respectively), whereas other lactation performance characteristics were not affected by 3 -NOP. Days in milk affected the majority of the lactation performance characteristics. Milk yield was lower $(P<0.001)$ at 111 DIM compared with both 27 and 55 DIM, whereas FPCM, ECM, and feed efficiency decreased from 27 DIM to both 55 and 83 DIM, and further to 111 DIM $(P<0.001)$, with no difference between 55 and 83 DIM. In contrast, milk urea content was higher at 111 DIM compared with both 27 and 55 DIM. Lactose yield was lower at 111 DIM compared with 27,55 , and 83 DIM $(P<0.001)$. Milk protein content was significantly affected by DIM $(P=0.044)$, but only tended to be higher at 111 DIM compared with 27 DIM. Fat yield $(\mathrm{g} / \mathrm{d})$ tended to decrease with advancing lactation stage $(P=0.067)$.

Table 2. Nutrient intake and apparent total-tract digestibility of nutrients of early lactation dairy cows fed diets with (3-NOP) or without (CON) 3-nitrooxypropanol supplementation

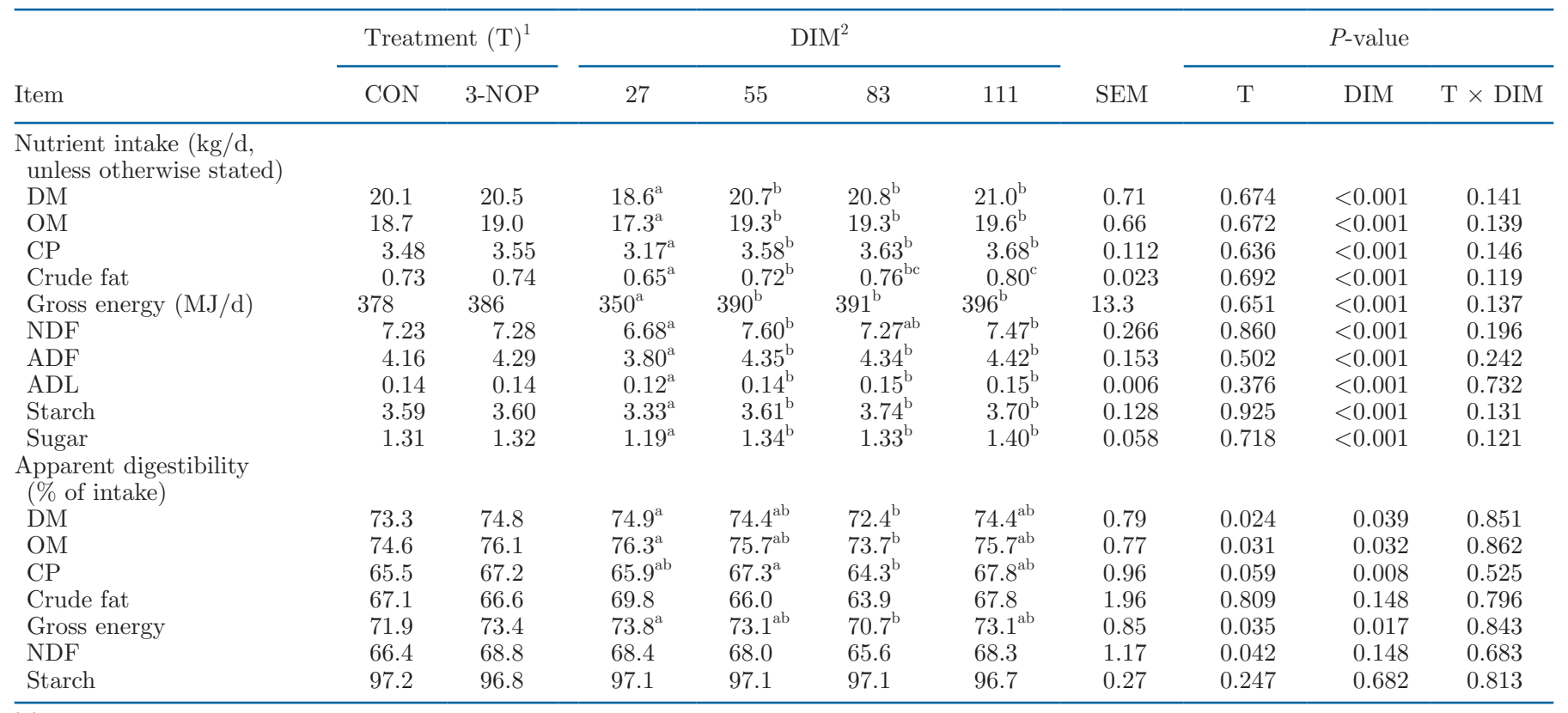

\footnotetext{
${ }^{\mathrm{a}-\mathrm{c}}$ Values with a different superscript letter indicate a significant difference between 27, 55, 83, and 111 DIM.

${ }^{1}$ Values reported as LSM for the CON and 3-NOP treatments, averaged over 27, 55, 83, and 111 DIM.

${ }^{2}$ Values reported as LSM for 27, 55, 83, and 111 DIM, averaged over the CON and 3-NOP treatments.
} 
van Gastelen et al.: 3-NITROOXYPROPANOL, LACTATION STAGE, AND METHANE EMISSIONS

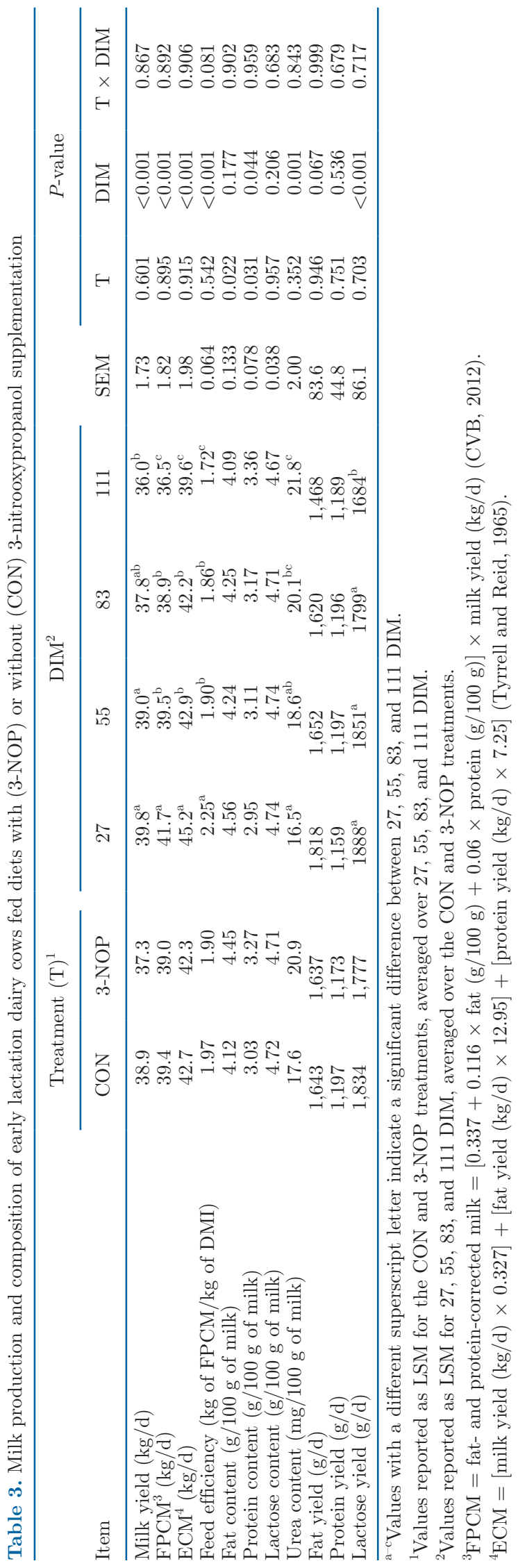

\section{Milk Fatty Acid Profile}

Three MFA (i.e., C17:0 iso, C17:0, and C17:1 cis-9) were affected by a treatment $\times$ DIM interaction $(P \leq$ 0.035; Table 4), and C12:0 and C18:1 trans-6 tended to be affected by a treatment $\times$ DIM interaction $(P \leq$ 0.095). The proportion of C17:0 iso was lower for the 3 -NOP treatment compared with the CON treatment, but only at 83 DIM. The proportion of $\mathrm{C} 17: 1$ cis-9 was lower for the 3-NOP treatment compared with the CON treatment, but only at 27 DIM. The proportion of C17:0 did not differ between the 3-NOP and the CON treatment at any DIM, but the proportion of C17:0 for the CON treatment was higher at 27 DIM than at any other DIM, whereas the proportion of C17:0 for the 3 -NOP treatment was not affected by DIM.

The proportion of MFA C6:0 and C8:0 were higher $(P \leq 0.046$; Table 4), and those of C10:0 and C12:0 tended to be higher $(P \leq 0.070)$, for the 3 -NOP treatment compared with the $\mathrm{CON}$ treatment. In contrast, the proportions of $\mathrm{C} 14: 0$ iso, C16:0 iso, C18:1 cis-11, C18:1 cis-12, C18:1 cis-13, C18:2n-6, and C18:3n-3 were lower $(P \leq 0.043)$, and the proportions of $\mathrm{C} 16: 1$ trans $-9, \mathrm{C} 18: 1$ trans -6 , and $\mathrm{C} 18: 1$ cis-14 tended to be lower $(P \leq 0.074)$ for the 3 -NOP treatment compared with the CON treatment. The ratio representing mammary synthase activity was greater $(P=0.026)$ with the 3-NOP treatment compared with the CON treatment. The group of SFA tended to increase, the group of UFA and MUFA tended to decrease, and the group of PUFA decreased $(P=0.024)$ for the 3 -NOP treatment compared with the CON treatment.

The short- and even-chain (i.e., <16C) fatty acids (FA), which are produced de novo in the mammary gland, generally increased with advancing lactation stage, with the exception of $\mathrm{C} 4: 0$, which was higher $(P<0.001)$ at 27 DIM compared with 55, 83, and 111 DIM (Table 4). The proportions of C6:0, C8:0, and C10:0 were lower $(P<0.001)$ at 27 DIM compared with 55, 83, and 111 DIM, and the proportions C12:0, C14:0, and C14:1 cis-9 increased from 27 DIM to both 55 and 83 DIM, and further to 111 DIM. Also, the ratio for mammary synthase activity increased $(P<$ 0.001 ) from 27 DIM to 55 DIM, and further to both 83 and 111 DIM. The proportions of C16:0 increased $(P<0.001)$ with increasing DIM, and $\mathrm{C} 16: 1$ cis-9 was higher at 27 DIM compared with 55, 83, and 11 DIM, whereas C16:1 trans-9 decreased from 27 DIM to 55 DIM, and further to both 83 and 111 DIM. The oddand branched-chain fatty acids (OBCFA) showed a more variable response. The proportions of both C15:0 and C15:0 iso were lower $(P \leq 0.005)$ at 27 DIM compared with 55, 83, and 111 DIM, and C15:0 anteiso 
Table 4. The milk fatty acid composition of early lactation dairy cows fed diets with (3-NOP) or without (CON) 3-nitrooxypropanol supplementation

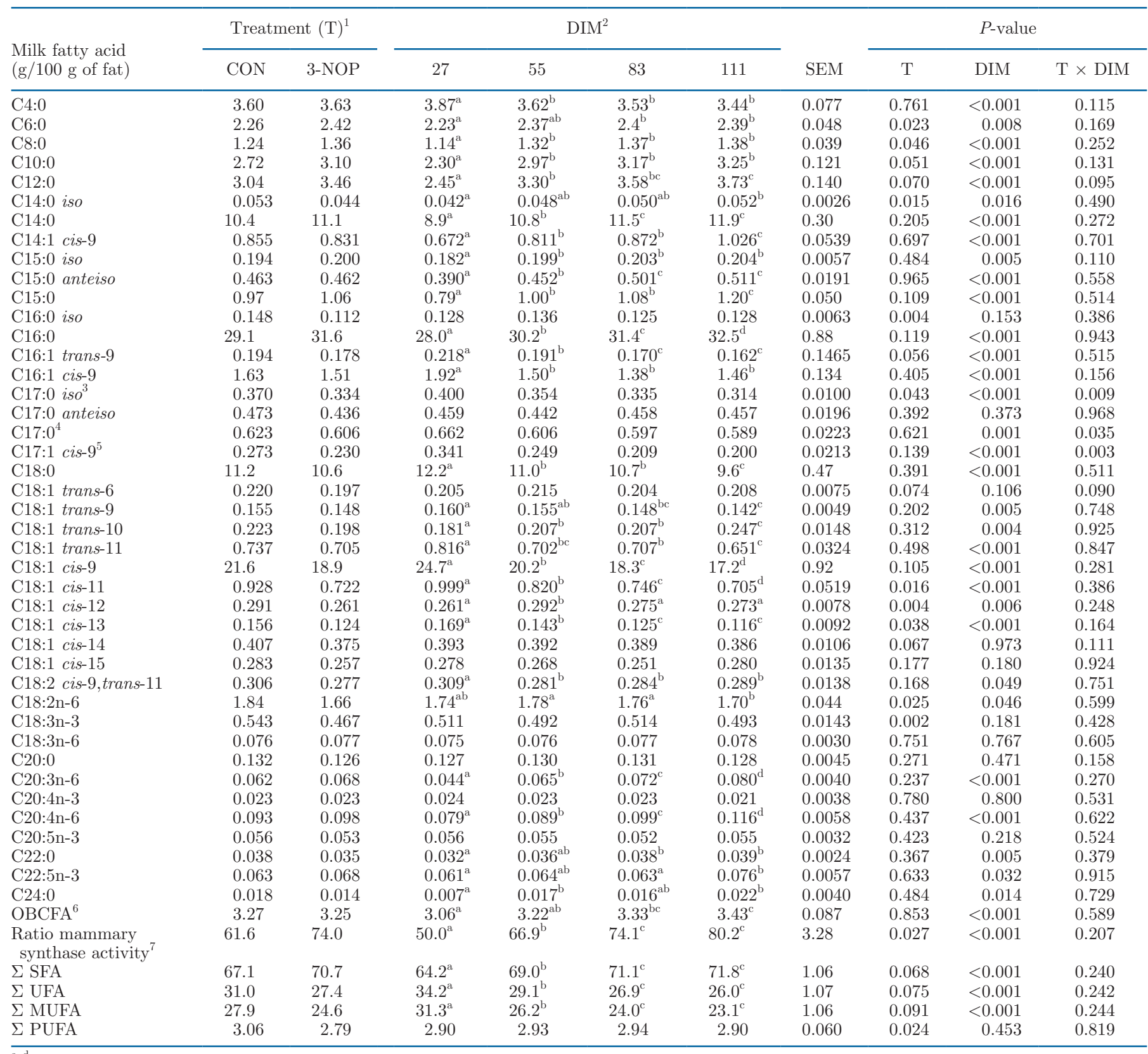

${ }^{\mathrm{a}-\mathrm{d}}$ Values with a different superscript letter indicate a significant difference between $27,55,83$, and 111 DIM.

${ }^{1}$ Values reported as LSM for the CON and 3-NOP treatments, averaged over 27, 55, 83, and 111 DIM.

${ }^{2}$ Values reported as LSM for 27, 55, 83, and 111 DIM, averaged over the CON and 3-NOP treatments.

${ }^{3} \mathrm{~T} \times$ DIM interaction; CON $27 \mathrm{DIM}=0.417, \mathrm{CON} 55 \mathrm{DIM}=0.362, \mathrm{CON} 83 \mathrm{DIM}=0.363^{*}, \mathrm{CON} 111 \mathrm{DIM}=0.324,3-\mathrm{NOP} 27 \mathrm{DIM}=0.384$, 3 -NOP 55 DIM $=0.342,3$-NOP 83 DIM $=0.306^{*}, 3-\mathrm{NOP} 111 \mathrm{DIM}=0.300 .{ }^{*}$ denotes CON is different $(P<0.05)$ from 3 -NOP at that stage of lactation.

${ }^{4} \mathrm{~T} \times$ DIM interaction; CON $27 \mathrm{DIM}=0.690, \mathrm{CON} 55 \mathrm{DIM}=0.588, \mathrm{CON} 83 \mathrm{DIM}=0.609, \mathrm{CON} 111 \mathrm{DIM}=0.576,3-\mathrm{NOP} 27 \mathrm{DIM}=0.633,3-\mathrm{NOP}$ $55 \mathrm{DIM}=0.613,3-\mathrm{NOP} 83 \mathrm{DIM}=0.580,3-\mathrm{NOP} 111 \mathrm{DIM}=0.590$.

${ }^{5} \mathrm{~T} \times$ DIM interaction; CON $27 \mathrm{DIM}=0.384^{*}, \mathrm{CON} 55 \mathrm{DIM}=0.257, \mathrm{CON} 83 \mathrm{DIM}=0.232, \mathrm{CON} 111 \mathrm{DIM}=0.192,3-\mathrm{NOP} 27 \mathrm{DIM}=0.294 *$, 3 -NOP $55 \mathrm{DIM}=0.237,3$-NOP $83 \mathrm{DIM}=0.184,3$-NOP $111 \mathrm{DIM}=0.196 .{ }^{*}$ denotes CON is different $(P<0.05)$ from 3 -NOP at that stage of lactation.

${ }^{6} \mathrm{Sum}$ of all odd- and branched-chain fatty acids (i.e., C14:0 iso, C15:0 iso, C15:0 anteiso, C15:0, C16:0 iso, C17:0 iso, C17:0 anteiso, and C17:0).

${ }^{7}$ The ratio between all de novo synthesized fatty acids (i.e., fatty acids with chain length of 4 to 14 C) and fatty acids with chain length of 18 to 24 C, multiplied by 100 . 
$(P<0.001)$ increased from 27 DIM to both 55 and 83 DIM, and further to 111 DIM.

The $\mathrm{C} 18$ isomers generally decreased with advancing lactating stage. The proportion of C18:2 cis-9, trans-11 was higher $(P=0.049)$ at 27 DIM compared with 55 , 83, and 111 DIM, and the proportions of C18:0, C18:1 trans-10, and C18:1 trans-11 decreased $(P \leq 0.004)$ from 27 DIM to both 55 and 83 DIM, and even further to 111 DIM. The proportion of C18:1 cis-13 decreased $(P \leq 0.001)$ from 27 DIM to 55 DIM, and even further to both 83 and 111 DIM, with no difference between the latter 2. The proportions of C18:1 cis-9 and C18:1 cis-11 decreased $(P<0.001)$ with advancing stage of lactation. Also, C18:1 trans-9 decreased, with a lower proportion for 83 and 111 DIM compared with 27 DIM.

The other long-chain (i.e., $\geq 20 \mathrm{C}$ ) FA showed a pattern similar to the short- and even-chain FA, and increased with advancing lactating stage. The proportions of both $\mathrm{C} 22: 0$ and $\mathrm{C} 24: 0$ were lower $(P \leq 0.014)$ at 27 DIM compared with 55, 83, and 111 DIM, the proportions of both $\mathrm{C} 20: 3 \mathrm{n}-6$ and $\mathrm{C} 20: 4 \mathrm{n}-6$ increased $(P<0.001)$ with advancing stage of lactation, and the proportion of $\mathrm{C} 22: 5 \mathrm{n}-3$ was higher $(P=0.032)$ at 111 DIM compared with 27 and 83 DIM. The sums of OBCFA and SFA increased $(P<0.001)$ with advancing lactating stage. The UFA and MUFA showed the opposite pattern; both decreased $(P<0.001)$ from 27 DIM to 55 DIM, and even further to both 83 and 111 DIM, with no differences between 83 and 111 DIM.

\section{Energy and Nitrogen Retention}

Treatment $\times$ DIM interactions were found for $\mathrm{CH}_{4}$ production $\left(\mathrm{kJ} / \mathrm{kg}\right.$ of $\mathrm{BW}^{0.75}$ per day), as well as $\mathrm{N}$ efficiency (the ratio of $\mathrm{N}$ in milk to ingested $\mathrm{N}$, in $\%)$. Methane production was lower $(P=0.021)$ with 3 -NOP at 55 and 111 DIM, but not at 27 and 83 DIM. Nitrogen efficiency did not differ between the CON and 3 -NOP treatment at any of the stages of lactation, but was higher $(P=0.026$; Table 5$)$ at 27 DIM compared with 55, 83, and 111 DIM for the CON treatment only. In comparison to the $\mathrm{CON}$ treatment, 3-NOP did not generally affect energy and $\mathrm{N}$ balance. Only the ratio between metabolizable energy intake (MEI) and gross energy intake (GEI) was affected by treatment; it was higher $(P=0.005)$ for the 3 -NOP treatment compared with the CON treatment.

In general, energy balance and its variables were affected by lactation stage. Energy intake, in the form of GEI and digestible energy intake, was lower $(P \leq$ 0.001 ) at 27 DIM compared with 55, 83, and 111 DIM. Metabolizable energy intake was lower $(P=0.016)$ at 27 DIM compared with 55 DIM. Energy in manure fol- lowed that same pattern $(P \leq 0.001)$, whereas energy excreted via milk decreased $(P<0.001)$ from 27 DIM to 83 DIM to 111 DIM. Overall, this resulted in lower $(P \leq 0.006)$, and sometimes negative, total energy retained and energy retained as protein and fat at 27 DIM compared with 55, 83, and 111 DIM. Days in milk also affected multiple $\mathrm{N}$ retention variables. The $\mathrm{N}$ intake and $\mathrm{N}$ balance were lower $(P \leq 0.006)$ at $27 \mathrm{DIM}$ compared with 55, 83, and 111 DIM. The $\mathrm{N}$ trapped in condensed water and in the sulfuric acid solution were lower $(P=0.019)$ at 27 DIM compared with 111 DIM.

\section{Gaseous Exchange}

Hydrogen yield (as g/ $\mathrm{kg}$ of DMI and as $\mathrm{g} / \mathrm{kg}$ of digestible $\mathrm{OM}$ intake; DOMI), $\mathrm{CH}_{4}$ production $(\mathrm{g} / \mathrm{d})$, and $\mathrm{CH}_{4}$ intensity (as $\mathrm{g} / \mathrm{kg}$ of FPCM and as $\mathrm{g} / \mathrm{kg}$ of ECM) were affected $(P \leq 0.039$; Table 6$)$, and the ratio between $\mathrm{CH}_{4}$ and $\mathrm{CO}_{2}$ tended to be affected $(P$ $=0.058)$, by treatment $\times$ DIM interactions. For both units of $\mathrm{H}_{2}$ yield, no differences between DIM were observed for the CON treatment, whereas for the 3-NOP treatment, $\mathrm{H}_{2}$ yield at 27 DIM was higher $(P \leq 0.034)$ compared with 55, 83, and 111 DIM. This interaction for $\mathrm{H}_{2}$ yield ( $\mathrm{g} / \mathrm{kg}$ of DMI) is also illustrated in Figure 1. For all stages of lactation, $\mathrm{H}_{2}$ yield was higher for the 3 -NOP treatment compared with the CON treatment; $\mathrm{H}_{2}$ yield of 3-NOP compared with CON was 15 times greater at 27 DIM, and declined to a range of 9 to 11 times greater at 55 to 111 DIM. For $\mathrm{CH}_{4}$ production $(\mathrm{g} / \mathrm{d}), 27$ DIM was lower $(P=0.005)$ than 55,83 , and 111 DIM for the $\mathrm{CON}$ treatment, but $\mathrm{CH}_{4}$ production was not affected by DIM for the 3-NOP treatment. This resulted in a difference in $\mathrm{CH}_{4}$ production between the CON treatment and the 3 -NOP treatment at 55 and 111 DIM, but not at 27 and 83 DIM (Figure 2). Despite the interaction observed for $\mathrm{CH}_{4}$ intensity, both as $\mathrm{g} /$ $\mathrm{kg}$ of FPCM and $\mathrm{g} / \mathrm{kg}$ of $\mathrm{ECM}, \mathrm{CH}_{4}$ intensity did not differ significantly between the 3-NOP treatment and the CON treatment at any lactation stage.

The emissions of $\mathrm{H}_{2}$, as production and as intensity, were affected by treatment, with higher $(P<0.001)$ emissions for the 3-NOP treatment compared with the CON treatment. Methane yield (expressed in $\mathrm{g} / \mathrm{kg}$ of DMI, $\mathrm{g} / \mathrm{kg}$ of DOMI, $\mathrm{g} / \mathrm{kg}$ of digestible NDF intake, and as \% of GEI) was lower $(P \leq 0.001)$ for the 3 -NOP treatment compared with the CON treatment. The $\mathrm{H}_{2}$ to $\mathrm{CH}_{4}$ ratio was higher $(P<0.001)$ for the 3 -NOP treatment compared with the $\mathrm{CON}$ treatment. The production of $\mathrm{CO}_{2}$ and the respiratory quotient were lower at 27 DIM $(P<0.001)$ compared with 55,83 , and 111 DIM. Of the $\mathrm{H}_{2}$ emissions, only $\mathrm{H}_{2}$ intensity (both as $\mathrm{g} / \mathrm{kg}$ of FPCM and $\mathrm{g} / \mathrm{kg}$ of ECM) was affected 
by DIM, with a higher $(P \leq 0.043) \mathrm{H}_{2}$ intensity at 111 DIM compared with only 27 DIM.

\section{BW Change}

Body weight change (expressed in \% of BW) between 27 and 55 DIM, between 55 and 83 DIM, and between 83 and 111 DIM was not affected by a treatment $\times$ between-DIM interaction $(P=0.532)$, tended $(P=$ $0.062)$ to be affected by between-DIM, and was $(P=$ 0.035 ) lower for the CON treatment compared with the 3-NOP treatment (Figure 3). Average BW change between 2 consecutive stages of lactation was $0.01 \%$ of BW with CON and $0.90 \%$ of BW with 3-NOP.

\section{DISCUSSION}

\section{Nutrient Intake and Digestibility}

No significant effects of feeding 3-NOP on DMI and nutrient intake of dairy cattle were found, which agrees with other studies (e.g., Hristov et al., 2015; Lopes et al., 2016). Only Melgar et al. (2020) reported a decreased DMI upon feeding 3-NOP to early lactation dairy cattle. The increased apparent total-tract digest-

Table 5. Energy $\left(\mathrm{kJ} / \mathrm{kg}\right.$ of $\mathrm{BW}^{0.75}$ per day, unless otherwise stated) and $\mathrm{N}$ balance $\left(\mathrm{mg} / \mathrm{kg}\right.$ of $\mathrm{BW}^{0.75}$ per day) of early lactation dairy cows fed diets with (3-NOP) or without (CON) 3-nitrooxypropanol supplementation

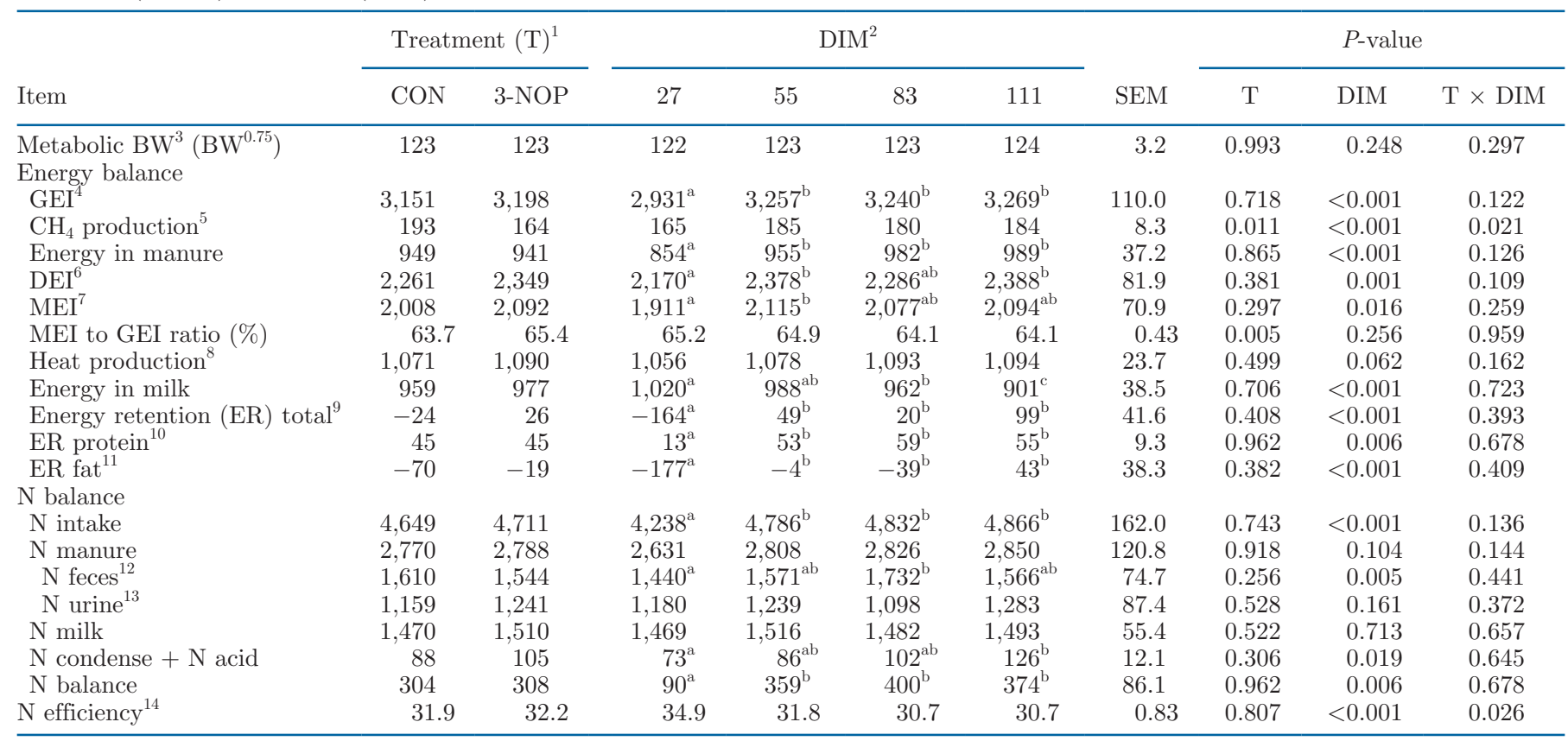

${ }^{\mathrm{a}-\mathrm{c}}$ Values with a different superscript letter indicate a significant difference between $27,55,83$, and 111 DIM.

${ }^{1}$ Values reported as LSM for the CON and 3-NOP treatments, averaged over 27, 55, 83, and 111 DIM.

${ }^{2}$ Values reported as LSM for 27, 55, 83, and 111 DIM, averaged over the CON and 3-NOP treatments.

${ }^{3}$ The mean BW per cow per balance period was used to calculate $\mathrm{BW}^{0.75}$.

${ }^{4} \mathrm{GEI}=$ gross energy intake.

${ }^{5} \mathrm{~T} \times \mathrm{DIM}$ interaction; control $27 \mathrm{DIM}=171$, control $55 \mathrm{DIM}=204^{*}$, control $83 \mathrm{DIM}=194$, control $111 \mathrm{DIM}=203^{*}, 3-\mathrm{NOP} 27 \mathrm{DIM}=160$, 3 -NOP 55 DIM $=166^{*}, 3$-NOP 83 DIM $=166,3$-NOP 111 DIM $=165^{*} .{ }^{*}$ denotes CON is different $(P<0.05)$ from 3 -NOP at that stage of lactation.

${ }^{6} \mathrm{DEI}($ digestible energy intake $)=$ GEI $\times$ apparent total-tract digestibility of GE $(\%$ of intake).

${ }^{7} \mathrm{MEI}$ (metabolizable energy intake) = GEI - methane production - energy in feces + urine.

${ }^{8}$ Heat production $(\mathrm{kJ} / \mathrm{d})=16.175 \times \mathrm{VO}_{2}(\mathrm{~L} / \mathrm{d})+5.021 \times \mathrm{VCO}_{2}(\mathrm{~L} / \mathrm{d})$, where $\mathrm{VO}_{2}=$ volumes of $\mathrm{O}_{2}$ consumed, and $\mathrm{VCO}_{2}=$ volumes of $\mathrm{CO}_{2}$ produced (Gerrits et al., 2015).

${ }^{9} \mathrm{ER}$ total $=\mathrm{MEI}-$ heat production - energy in milk.

${ }^{10} \mathrm{ER}$ protein $=$ protein gain $(\mathrm{N} \times 6.25) \times 23.6 \mathrm{~kJ} / \mathrm{g}$ (energetic value of protein $)$.

${ }^{11} \mathrm{ER}$ fat $=\mathrm{ER}$ total $-\mathrm{ER}$ protein

${ }^{12} \mathrm{~N}$ feces $=\mathrm{N}$ intake $\times[100-$ apparent total-tract digestibility of $\mathrm{N}(\%$ of intake $)]$.

${ }^{13} \mathrm{~N}$ urine $=\mathrm{N}$ manure $-\mathrm{N}$ feces.

${ }^{14} \mathrm{~N}$ efficiency $=\mathrm{N}$ milk $/ \mathrm{N}$ feed $(\%) . \mathrm{T} \times \mathrm{DIM}$ interaction; CON $27 \mathrm{DIM}=36.0, \mathrm{CON} 55 \mathrm{DIM}=31.1, \mathrm{CON} 83 \mathrm{DIM}=30.3, \mathrm{CON} 111 \mathrm{DIM}=$ $30.1,3$-NOP 27 DIM = 33.7, 3-NOP 55 DIM = 32.5, 3-NOP 83 DIM = 31.2, 3-NOP 111 DIM = 31.4. 
van Gastelen et al.: 3-NITROOXYPROPANOL, LACTATION STAGE, AND METHANE EMISSIONS

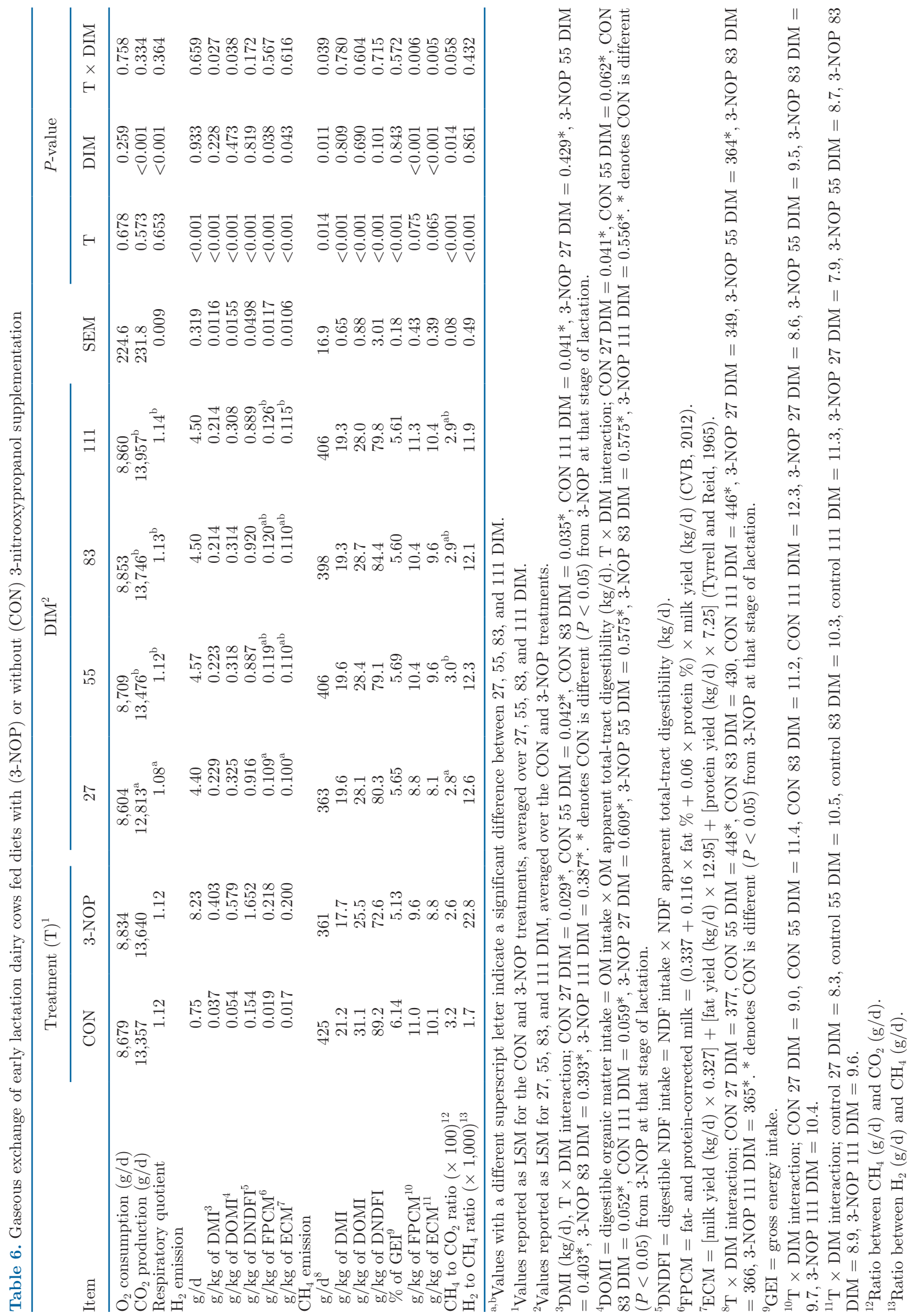



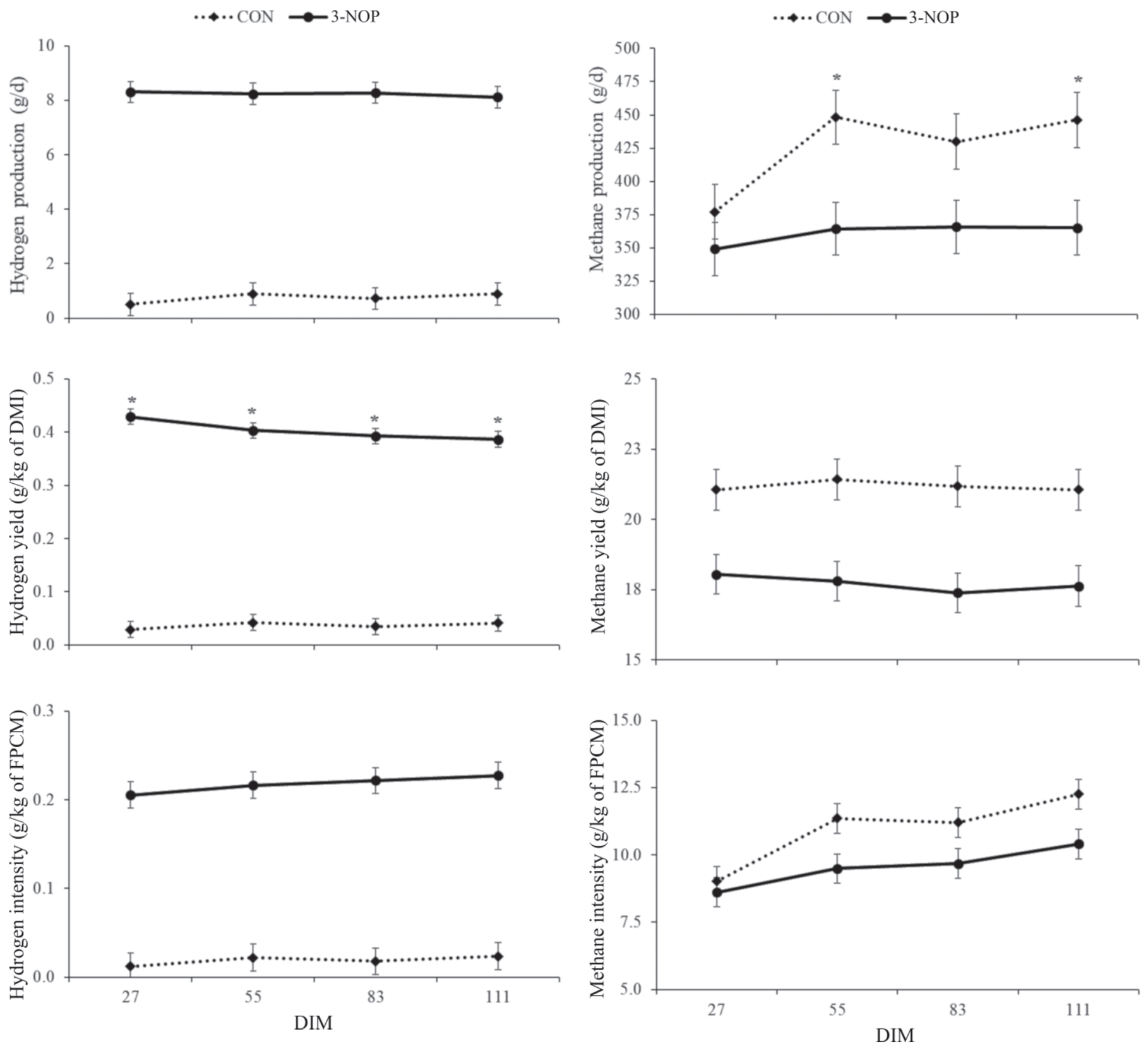

Figure 1. Hydrogen production (g/d; upper panel), hydrogen yield ( $\mathrm{g} / \mathrm{kg}$ of DMI; middle panel), and hydrogen intensity $(\mathrm{g} / \mathrm{kg}$ of fat- and protein-corrected milk, FPCM; lower panel) of early lactation dairy cows treated with (3-NOP) or without (CON) 3-nitrooxypropanol at different stages of lactation (27 DIM, 55 DIM, 83 DIM, and 111 DIM). Data are treatment least squares means and bars represent $\mathrm{SE} ; \mathrm{n}=$ 8 . In the case of a significant treatment $\times$ DIM interaction, $*$ denotes CON is different $(P<0.05)$ from 3 -NOP at that stage of lactation.

ibility of several nutrients upon feeding 3 -NOP in the present study is in line with the findings of Haisan et al. (2017; significant improved digestibility of DM and NDF with the high, but not with the low level of feeding 3-NOP), Hristov et al. (2015; significant quadratic effect of 3-NOP on digestibility of DM, CP, and ADF),

Figure 2. Methane production (g/d; upper panel), methane yield $(\mathrm{g} / \mathrm{kg}$ of DMI; middle panel), and methane intensity $(\mathrm{g} / \mathrm{kg}$ of fat- and protein-corrected milk, FPCM; lower panel) of early lactation dairy cows treated with (3-NOP) or without (CON) 3-nitrooxypropanol at different stages of lactation (27 DIM, 55 DIM, 83 DIM, and 111 DIM). Data are treatment least squares means and bars represent SE; $\mathrm{n}=$ 8. In the case of a significant treatment $\times$ DIM interaction, $*$ denotes $\mathrm{CON}$ is different $(P<0.05)$ from $3-\mathrm{NOP}$ at that stage of lactation.

and Melgar et al. (2020; significant improved digestibility of CP with 3-NOP). It may be hypothesized (feeding behavior as such was not measured in the present study) that this improved digestibility is related to a more efficient ruminal fermentation with 3 -NOP due to a different feeding pattern. Others have reported 


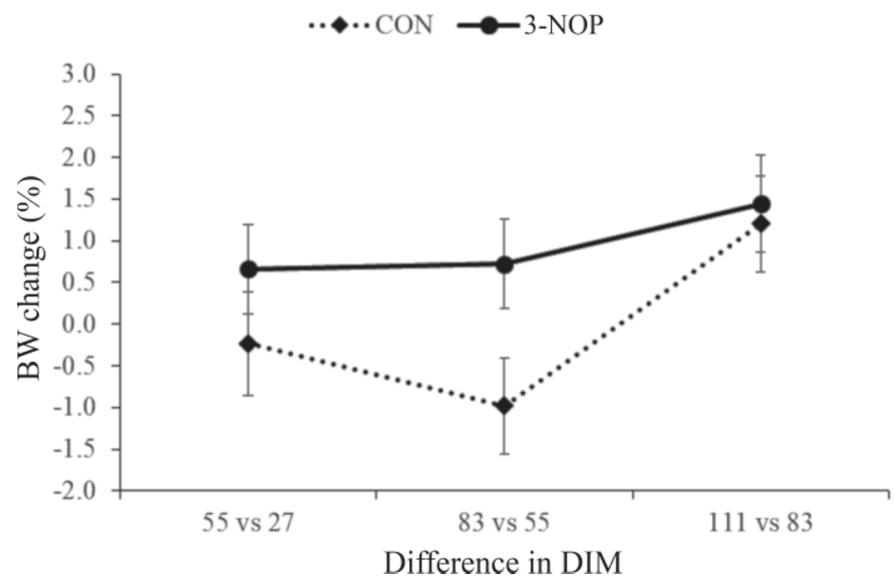

Figure 3. Body weight change (\%) of early lactation dairy cows treated with (3-NOP) or without (CON) 3-nitrooxypropanol between 27 and 55 DIM, between 55 and 83 DIM, and between 83 and 111 DIM. Data are treatment least squares means and bars represent SE; $\mathrm{n}=8$.

increased propionate proportions at the expense of acetate proportions in rumen fluid upon feeding 3-NOP (Haisan et al., 2014; Reynolds et al., 2014; Hristov et al., 2015). Propionate concentrations in blood affect satiety (Allen, 2000). This may change feeding behavior, possibly resulting in shorter meals, but more meals per day for the 3-NOP fed cows compared with the CON fed cows to reach the same DMI. Subsequently, the increased feeding frequency of the 3-NOP fed cows may result in a more stable ruminal $\mathrm{pH}$ (French and Kennelly, 1990), potentially resulting in a more efficient ruminal fermentation. However, Kim et al. (2019) recently demonstrated that dietary supplementation of 3-NOP did not affect feeding behavior of beef steers fed a high forage or high grain diet. Effects of 3-NOP on feed intake pattern and meal size, as well as the mechanisms by which beneficial effects on digestibility were exerted in some studies, remain to be investigated in dairy cattle.

Generally, feed intake capacity of multiparous dairy cattle increases rapidly during the first 2 mo after calving, followed by a slower increase until approximately 100 DIM, followed by a gradual decline toward the end of lactation (Zom et al., 2012). In accordance, nutrient intake in the current study was lower at 27 DIM compared with 55, 83, and 111 DIM. However, nutrient intake did not increase further from 55 DIM up to 111 DIM.

The decreased apparent total-tract digestibility of DM, OM, CP, and GE at 83 DIM compared with 27 and 55 DIM was unexpected. An increase in feed intake can potentially result in a decrease in digestibility (Colucci et al., 1989) as a result of a shorter retention time in the rumen, increased fractional passage rate, and decreased ruminal fermentation. However, DMI did not increase after 55 DIM in the current study and, hence, cannot explain the decreased digestibility observed at 83 DIM. Dietary composition (e.g., concentrate proportion) did not change with advanced lactation stage during the experiment. In other trials, changes in apparent total-tract digestibility at different stages of lactation occurred, but these changes were related to changes in dietary forage to concentrate ratio (Hartnell and Satter, 1979). The chemical composition of the TMR fed at 83 DIM did not appear to differ from the TMR fed at 27, 55, and 111 DIM (Table 1), and therefore the observed change in total-tract digestibility is unlikely to be caused by poorer quality of the silages or concentrate fed to cattle at 83 DIM compared with 27,55 , and 111 DIM.

\section{Lactation Performance}

No effects of feeding 3-NOP on milk production and feed efficiency were found, which agrees with other studies on 3-NOP in dairy cattle. Only Melgar et al. (2020) reported an increased feed efficiency, relative to both milk yield $(\mathrm{kg} / \mathrm{d})$ and ECM $(\mathrm{kg} / \mathrm{d})$, upon feeding 3 -NOP to dairy cattle in early lactation. The increased milk protein content and milk fat content upon feeding 3-NOP observed in the present study agrees with Reynolds et al. (2014), who reported a positive effect of 3-NOP on milk protein content, and with Lopes et al. (2016), who reported a positive effect of 3-NOP on milk fat content.

The decreased milk yield from 27 DIM to 111 DIM is in line with the generally accepted lactation curve (Grossman and Koops, 1988). The high milk yield, in combination with the relatively low DMI at 27 DIM, explains the highest feed efficiency at 27 DIM. This may result from a genetic potential for high milk production accompanied by a delay in feed intake postpartum, resulting in a negative energy balance in high production dairy cows in early lactation (Veerkamp et al., 2003). At 27 DIM, cows were in negative energy balance, using body reserves for maintenance and milk production, which also helps to explain the high feed efficiency at 27 DIM. From 55 DIM onwards, feed efficiency decreased due to the decreasing milk yield and unchanged DMI; this is also reflected in a change in energy balance (a change from negative at 27 DIM to positive at 55 to 111 DIM). The increase in milk urea content with advancing lactation stage is in agreement with literature (Carlsson et al., 1995; Arunvipas et al., 2003; Jílek et al., 2006) and may result from the inability of dairy cows to ingest or digest a sufficient amount of feed during the initial weeks of lactation, resulting in a low intake of protein relative to milk protein output 
(Carlsson et al., 1995; Table 2) and likely low AA oxidation (Shalit et al., 1991; Maltz and Silanikove, 1996). Milk urea concentration may serve as an indicator of $\mathrm{N}$ excretion and milk $\mathrm{N}$ efficiency, but the relationship between milk urea and $\mathrm{N}$ excretion is variable (Spek et al., 2013). Results of the present experiment indicate that milk urea concentration is not necessarily a sound indicator of milk $\mathrm{N}$ efficiency. The general decrease in milk $\mathrm{N}$ efficiency with advancing lactation stage was reflected in increased milk urea levels, but the interaction between treatment and DIM for milk $\mathrm{N}$ efficiency was not present for milk urea content.

\section{Milk Fatty Acid Profile}

Treatment $\times$ DIM interactions were observed for C17:0, C17:0 iso, and C17:1 cis-9. Propionate, produced in the rumen, is a substrate for de novo synthesis of C17:0 in the mammary gland (van Gastelen and Dijkstra, 2016). Additionally, milk OBCFA (including C17:0 and C17:0 iso) are of microbial origin in the rumen. Fibrolytic bacteria are generally enriched in iso FA, whereas amylolytic bacteria contain relatively high amounts of linear odd-chain FA and anteiso FA (Vlaeminck et al., 2006). The $\mathrm{C} 17: 1$ cis-9 originates from $\mathrm{C} 17: 0$ and $\Delta^{9}$-desaturase enzymes, adding a cis-9 double bond (Pereira et al., 2003). It is unclear why these processes would be affected by treatment $\times$ DIM interactions, but it might be related to an adapting microbiota. Changes in the microbiome with time as lactation advances can result in changes in the fermentation profile, as well as propionate production.

The individual short- and even-chain FA $(<16 \mathrm{C})$ and the ratio of de novo synthesized FA relative to preformed FA (reflecting mammary synthase activity; Garnsworthy et al., 2006) were higher for the 3-NOP treatment compared with the CON treatment. This is largely in agreement with Hristov et al. (2015) and Melgar et al. (2020), but contrary to Reynolds et al. (2014), who reported no effects of feeding 3 -NOP on short- and even-chain FA in milk. Milk short- and even-chain FA are synthesized de novo in the mammary gland primarily from acetate (Bauman and Griinari, 2003) and indirectly from butyrate (Dijkstra et al., 2011), originating from ruminal fermentation. Ruminal VFA proportions were not measured in the current study, but other studies consistently report increased propionate proportions at the expense of acetate proportions in rumen fluid with feeding of 3-NOP (Haisan et al., 2014; Reynolds et al., 2014; Hristov et al., 2015). A decrease in ruminal acetate may also be accompanied with an increase in ruminal butyrate. Although not measured in the present study, other studies report an increased ruminal butyrate and decreased acetate proportion upon feed- ing of 3-NOP (Melgar et al., 2020). Ruminal butyrate is absorbed through the rumen wall and is mostly metabolized by rumen epithelial cells as an energy source or converted into $\beta$-hydroxybutyrate, when it becomes a source of carbon in the mammary gland, and can be used as a primer for short- and even-chain milk FA synthesis (Bergman, 1990; Bauman and Griinari, 2003).

Milk iso OBCFA were generally lower with the 3 -NOP treatment compared with the CON treatment. Milk OBCFA are of microbial origin in the rumen, with iso OBCFA more abundant in fibrolytic bacteria (Vlaeminck et al., 2006). Lopes et al. (2016) reported decreased relative abundance of fibrolytic bacteria, such as Ruminococcus spp., upon feeding 3-NOP, which may explain the MFA findings of the present study. However, a decline in the relative abundance of fibrolytic bacteria is not in line with the observed improvement of total-tract NDF digestion, although relative abundance does not necessarily reflect the absolute abundance and its potential effect on NDF digestion.

The long-chain MFA $(\geq 18 \mathrm{C})$ were generally unaffected upon feeding 3-NOP, with the exception of some cis $\mathrm{C} 18: 1$ isomers, $\mathrm{C} 18: 2 \mathrm{n}-6$, and $\mathrm{C} 18: 3 \mathrm{n}-3$, which were lower for the 3 -NOP treatment compared with the CON treatment. This is contrary to the findings of Reynolds et al. (2014) and Melgar et al. (2020), who found no effects of 3-NOP on these MFA, and Hristov et al. (2015), who reported effects mainly on trans C18:1 isomers upon feeding 3-NOP. The decrease in the proportion of long-chain MFA in the current study might be due to reporting the MFA profile in $\mathrm{g} / 100 \mathrm{~g}$ of FA. The relative increase of de novo synthesized FA with 3-NOP compared with CON (as reported above) may have resulted in the decrease of the proportion of longchain MFA in milk fat. However, milk fat yield did not differ between the CON and 3-NOP treatments, making the proportional changes similar to yield changes. Alternatively, long-chain MFA originate from dietary FA and their biohydrogenation products formed in the rumen, and may originate from mobilized body fat resources during negative energy balance, in particular. Given that diet composition, and therefore dietary supply, of C18:2n-6 and C18:3n-3 did not differ between the $\mathrm{CON}$ and 3 -NOP treatments, and that the energy balance of the cows receiving $\mathrm{CON}$ or $3-\mathrm{NOP}$ did not differ, the decreased proportions of these FA in milk fat with 3-NOP indicate a different biohydrogenation activity in the rumen with 3-NOP. Biohydrogenation serves to alleviate toxicity of PUFA; certain dietary strategies, such as low-fiber diets and high-concentrate diets, can alter the rumen environment, resulting in a lower ruminal $\mathrm{pH}$ and, subsequently, in changes in the microbial population and microbial processes. These changes involve alterations in the biohydrogena- 
tion pathways, potentially resulting in the formation of C18:1 trans-10 and related intermediates (Bauman and Griinari, 2003). Ruminal pH was not measured in the present study, but Haisan et al. (2017) and Lopes et al. (2016) reported no effects of 3 -NOP on ruminal $\mathrm{pH}$, and Melgar et al. (2020) observed a higher ruminal $\mathrm{pH}$ upon feeding 3-NOP. These reported $\mathrm{pH}$ responses in other studies are contrary to the theory potentially explaining the observed decrease in the proportion of long-chain MFA in the current study.

Palmquist et al. (1993) and Auldist et al. (1998) reported lower proportions of short- and even-chain FA $(<16 \mathrm{C})$ in milk of cows in early lactation compared with cows in mid lactation, and concluded that de novo synthesis of these FA was negatively related to longchain FA derived from body fat mobilization. This was also observed in the current study, where the proportion of short- and even-chain MFA, and the ratio reflecting mammary synthase activity, were lower at 27 DIM compared with 55, 83, and 111 DIM. Only C4:0 was higher at 27 DIM compared with 55, 83, and 111 DIM, which is in agreement with Garnsworthy et al. (2006). This could be related to body fat mobilization and, consequently, higher plasma $\beta$-hydroxybutyrate concentrations (van Knegsel et al., 2007b). Approximately 50\% of $\mathrm{C} 4: 0$ in the milk is produced from ruminal acetate, and the other $50 \%$ of $\mathrm{C} 4: 0$ in the milk is produced from $\beta$-hydroxybutyrate (Moore and Christie, 1981). Thus, it is possible that the elevated C4:0 proportions in milk at 27 DIM reflects an elevated substrate supply.

Several studies have shown that dairy cows are usually in negative energy balance in early lactation and mobilize considerable amounts of body fat (Garnsworthy and Topps, 1982; van Knegsel et al., 2007a). In adipose tissue, C16:0, C18:0, and C18:1 cis-9 account for nearly $90 \%$ of $\mathrm{FA}$ in roughly equal molar proportions (Christie, 1981). When body fat mobilization occurs, increased incorporation of these FA into milk fat is expected. This was observed in the current study for C18:0 and C18:1 cis-9, but not for C16:0, which is in agreement with Stoop et al. (2009). The latter is probably because de novo synthesis of C16:0 was reduced or C16:0 was catabolized for other purposes (Garnsworthy et al., 2006). Similar to Kay et al. (2005), C18 isomers generally decreased with advancing lactating stage, likely due to a decrease in body fat mobilization. The lower proportion of long-chain MFA with $>20$ carbons at 27 DIM might be related to a reduced activity of elongases (Pereira et al., 2003).

\section{Energy and Nitrogen Retention}

The production of $\mathrm{CH}_{4}$ is a determinant of energy balance, and will be discussed in the Gaseous Exchange section. The interaction between treatment and DIM for milk $\mathrm{N}$ efficiency is difficult to explain based on biological reasoning, but is likely the result of the relative lower $\mathrm{N}$ intake (i.e., numerical larger difference) for the CON treatment at 27 DIM compared with 55,83 , and 111 DIM, and compared with $\mathrm{N}$ intake achieved with the 3-NOP treatment at 27 DIM.

The MEI to GEI ratio was greater with 3-NOP than with CON. Haisan et al. (2017) reported that the total net energy expenditure for maintenance and lactation, calculated as per NRC (2001), was unaffected by feeding 3-NOP. Reynolds et al. (2014), who provided a pulse dose of 3-NOP directly into the rumen, found none of the energy balance variables to be affected by 3 -NOP, with the exception of lower $\mathrm{CH}_{4}$ production (low and high 3-NOP levels) and total energy balance (only at high 3-NOP level). Decreases in $\mathrm{CH}_{4}$ production may provide more MEI for productive purposes, such as milk energy production or tissue energy retention (Blaxter and Czerkawski, 1966). However, reductions in $\mathrm{CH}_{4}$ production are not always accompanied by increases in energy balance in lactating dairy cows, even when digestible energy intake is not affected (van Zijderveld et al., 2011). Although energy retention was numerically higher (positive value) for the 3-NOP treated cows compared with placebo treated cows (negative value) in the present study, this remained statistically insignificant. To be consistent with the published calculations of ME (van Knegsel et al., 2007a; Reynolds et al., 2014; van Gastelen et al., 2015), we did not subtract energy losses in $\mathrm{H}_{2}$ from $\mathrm{DE}$. In terms of energy, these $\mathrm{H}_{2}$ losses are on average $0.64 \mathrm{MJ} / \mathrm{d}$, and were only a minor proportion $(0.3 \%)$ of $\mathrm{ME}$ intake.

The $\mathrm{N}$ balance was not affected by the 3-NOP treatment compared with the CON treatment in the present study. This is contrary to the findings of Reynolds et al. (2014), who observed an increase in fecal N excreted, as well as a tendency of decreased milk $\mathrm{N}$ efficiency upon feeding 3-NOP. The findings of Reynolds et al. (2014) might originate from the way 3-NOP was supplied to the cows, twice daily directly into the rumen at feeding time. However, Melgar et al. (2020) reported a decreased $\mathrm{N}$ excretion in feces, as well as in total $\mathrm{N}$ excretion upon feeding 3-NOP, although $\mathrm{N}$ secretion in milk was unaffected.

The energy balance changes with lactation stage are according to expectations and in agreement with van Knegsel et al. (2007a). The dairy cows were in negative energy balance at 27 DIM and were mobilizing body fat reserves. Energy retained as protein was positive for all lactation stages, which agrees with Tamminga et al. (1997), who estimated changes in body composition with time after parturition. They reported that for protein, mobilization changed to retention at 5 
wh postpartum. The unaffected $\mathrm{N}$ excreted via urine suggests that the amount of protein catabolized is, on average, $26 \%$ of $\mathrm{N}$ for all stages of lactation intake. This illustrates that AA oxidation was not enhanced when cows were in negative energy balance at 27 DIM, which appears to be contrary to other studies (Shalit et al., 1991; Maltz and Silanikove, 1996).

\section{Gaseous Exchange}

The production of $\mathrm{CH}_{4}$ (both as $\mathrm{g} / \mathrm{d}$ and as $\mathrm{kJ} / \mathrm{kg}$ of $\mathrm{BW}^{0.75} / \mathrm{d}$ ) and $\mathrm{CH}_{4}$ intensity (both as $\mathrm{g} / \mathrm{kg}$ of FPCM and as $\mathrm{g} / \mathrm{kg}$ of ECM) were affected by a treatment $\times$ DIM interaction. This interaction appears to result from the difference in feed intake observed between the different stages of lactation, and DMI as a major determinant for both $\mathrm{CH}_{4}$ emissions and milk production. When correcting for these differences in feed intake and expressing $\mathrm{CH}_{4}$ as yield (relative to DMI, digestible OM intake, digestible NDF intake, or as \% of GEI), $\mathrm{CH}_{4}$ emissions were persistently lower throughout the whole early lactation period with 3 -NOP compared with CON. This is similar to the findings of Melgar et al. (2020), who reported no interaction between $\mathrm{CH}_{4}$ production $(\mathrm{g} / \mathrm{d})$ and the week of the study.

The interaction observed for $\mathrm{H}_{2}$ yield $(\mathrm{g} / \mathrm{kg}$ of DMI and $\mathrm{g} / \mathrm{kg}$ of DOMI) appeared to result from adaptation mechanisms upon feeding 3-NOP. The $\mathrm{H}_{2}$ yield at $27 \mathrm{DIM}$ for the 3 -NOP treatment is $6 \%, 9 \%$, and $11 \%$ higher than the $\mathrm{H}_{2}$ yield at 55, 83, and 111 DIM, respectively, whereas $\mathrm{H}_{2}$ yield did not differ between the different stages of lactation for the CON treatment. Similarly, Hristov et al. (2015) observed decreasing $\mathrm{H}_{2}$ emissions from 6 wk after introducing 3-NOP to the end of the experiment (wk 12). The decrease in $\mathrm{H}_{2}$ yield after 27 DIM can be the result of a change in the Archaea populations or of a redirection of $\mathrm{H}_{2}$ to alternative $\mathrm{H}_{2}$ sinks. Duin et al. (2016) indicated that both archaeal growth and methanogenesis stopped almost immediately upon the addition of 3 -NOP in vitro, but growth and $\mathrm{CH}_{4}$ formation resumed after the addition of 3-NOP was stopped. Methanogens contain a repair system that can reactivate methyl-coenzyme M reductase (Zhou et al., 2013; Prakash et al., 2014). Hence, inhibition of methanogenesis appears to be reversible in vivo (Duin et al., 2016). However, this adaptation mechanism was not apparent in the present study because $\mathrm{CH}_{4}$ emissions were not affected by treatment $\times$ DIM interactions (except $\mathrm{CH}_{4}$ production and intensity, most likely caused by differences in feed intake as described earlier). Propionate formation is an alternative electron-accepting pathway to $\mathrm{H}_{2}$ formation (Janssen, 2010). Therefore, 3-NOP supplementation is not only associated with an increase in $\mathrm{H}_{2}$ forma- tion and accumulation in the rumen, but may also be associated with an increase in the proportion of propionate as an end product of fermentation. Hence, we speculate that over time a redirected rumen fermentation-toward more propionate as an alternative to $\mathrm{H}_{2}$ formation - was activated; further studies with respect to VFA molar proportions and their development in time upon 3-NOP addition to the diet are required to evaluate this hypothesis.

Similar to previous studies in dairy cattle (Haisan et al., 2014; 2017; Hristov et al., 2015; Lopes et al., 2016; Melgar et al., 2020), including 3-NOP in diet decreased cattle $\mathrm{CH}_{4}$ emissions. On average (considering all $\mathrm{CH}_{4}$ emission units), we observed a $15.8 \%$ reduction in $\mathrm{CH}_{4}$ emissions for 3-NOP compared with CON. Other studies reported mitigation percentages ranging from $7 \%$ (Reynolds et al., 2014) to 60\% (Haisan et al., 2014). The lower mitigation in Reynolds et al. (2014) seems to be the result of the method of 3-NOP supplementation to the cows: pulse dosing twice daily at feeding time directly into the rumen through the rumen fistula. In most other studies, 3-NOP was mixed into the TMR, and mitigation percentages were on average $30 \%$ with the same target concentration of $3-\mathrm{NOP}$ (60 $\mathrm{mg} / \mathrm{kg}$ of DM) in the daily ration. The smaller decrease in $\mathrm{CH}_{4}$ emission in the present study can be partially explained by the greater NDF content of the diet, the observed increase of the apparent total-tract digestibility of several nutrients with 3-NOP, as well as by the dose of 3 -NOP fed to the dairy cows. The average NDF content of the present study was $358 \mathrm{~g} / \mathrm{kg}$ of DM, which is considerably higher than that of Lopes et al. (2016; $309 \mathrm{~g}$ of NDF / kg of DM), Hristov et al. (2015; $276 \mathrm{~g}$ of NDF/ $\mathrm{kg}$ of DM), and Haisan et al. (2017; $308 \mathrm{~g}$ of NDF $/ \mathrm{kg}$ of $\mathrm{DM})$. This represents, on average, a difference of some $60 \mathrm{~g}$ of NDF $/ \mathrm{kg}$ of DM. According to the meta-analysis of Dijkstra et al. (2018), the effect of feeding 3-NOP on $\mathrm{CH}_{4}$ emission is negatively related to dietary NDF content, where a greater dietary NDF content reduced the 3-NOP effect on $\mathrm{CH}_{4}$ yield by $1.52 \pm 0.406 \%$ per 10 $\mathrm{g} / \mathrm{kg}$ of DM increase in NDF content. Hence, the difference in dietary NDF content between the current study and other studies can result in an additional difference of $9 \%$ in $\mathrm{CH}_{4}$ mitigation. Additionally, an increased apparent total-tract digestibility suggests that the digestion of certain nutrients increased in the rumen or large intestine, with extra enteric $\mathrm{CH}_{4}$ production per kilogram of DM ingested. Another explanation for the smaller decrease in $\mathrm{CH}_{4}$ emission than expected is the recovery of 3-NOP in the dietary treatment. The target inclusion level of $3-\mathrm{NOP}$ was $60 \mathrm{mg} / \mathrm{kg}$ of DM. However, the average 3 -NOP recovery was $86.8 \%$, which equals an inclusion level of $51 \mathrm{mg} / \mathrm{kg}$ of DM. Dijkstra et al. (2018) concluded, based on a meta-analysis, that 
the effect of feeding 3-NOP on $\mathrm{CH}_{4}$ emission is dose dependent. From our present experiment with average $3-\mathrm{NOP}$ and NDF concentrations of $51 \mathrm{mg} / \mathrm{kg}$ of $\mathrm{DM}$ and $358 \mathrm{~g} / \mathrm{kg}$ of NDF, respectively, the model from Dijkstra et al. (2018) predicts a decline in $\mathrm{CH}_{4}$ emission of $16.4 \%\left(\mathrm{CH}_{4}\right.$ production $)$ and $17.1 \%\left(\mathrm{CH}_{4}\right.$ yield $)$, which is slightly greater than that observed $\left(\mathrm{CH}_{4}\right.$ production, decline of $15.1 \% ; \mathrm{CH}_{4}$ yield, decline of $16.3 \%$ ).

The increased $\mathrm{H}_{2}$ emission of the present study is in line with the findings of Hristov et al. (2015) and Lopes et al. (2016), although the observed increase in $\mathrm{H}_{2}$ production $(7.5 \mathrm{~g} / \mathrm{d})$ in our respiration chambers was far greater than that measured using the GreenFeed system in Hristov et al. $(2015 ; 3-\mathrm{NOP}=80 \mathrm{mg} /$ $\mathrm{kg}$ of DM) and Lopes et al. (2016; 3-NOP $=60 \mathrm{mg} /$ $\mathrm{kg}$ of $\mathrm{DM}$ ) (both $1.3 \mathrm{~g} / \mathrm{d}$ ) as well as in Melgar et al. (2020; $0.47 \mathrm{~g}$ of $\mathrm{H}_{2} / \mathrm{d}$ ). In general, accumulation of $\mathrm{H}_{2}$ in the rumen may result in the production of relatively more propionate as a fermentation end product, acting as a net sink for $\mathrm{H}_{2}$ (van Lingen et al., 2016). In the current study, we did not analyze ruminal VFA concentrations. However, the more than 10-fold increase in $\mathrm{H}_{2}$ emissions, as well as the high recovery of $\mathrm{H}_{2}$ in the CRC facilities (on average 96\%), indicates that $\mathrm{H}_{2}$ was measured accurately. Additionally, the lack of a negative effect on fiber digestibility or feed intake indicates that the rumen microbiota were able to cope with excess of $\mathrm{H}_{2}$ formed with 3-NOP addition. With a strong increase in $\mathrm{H}_{2}$ concentration in the rumen, it is likely that the proportion of propionate in total VFA was strongly elevated as well (van Lingen et al., 2016). The amount of $\mathrm{H}_{2}$ emitted from the rumen was only a fraction of the stoichiometric amount involved with the decrease in $\mathrm{CH}_{4}$ production as $\mathrm{H}_{2}$ sink. This was also observed by Hristov et al. (2015). The difference in $\mathrm{CH}_{4}$ emissions between the cows receiving the $\mathrm{CON}$ treatment and the cows receiving the 3 -NOP treatment was $64 \mathrm{~g} / \mathrm{d}$, which equals $4 \mathrm{~mol}$ of $\mathrm{CH}_{4} / \mathrm{d}$. On a molar basis, per mol of $\mathrm{CH}_{4}$ decrease, $4 \mathrm{~mol}$ of $\mathrm{H}_{2}$ remains unused (Czerkawski, 1986). Hence, $16 \mathrm{~mol}$ of $\mathrm{H}_{2} / \mathrm{d}$, which equals $32.2 \mathrm{~g}$ of $\mathrm{H}_{2} / \mathrm{d}$, remained unused with the observed decrease in $\mathrm{CH}_{4}$ emission in the present study. This is a far greater amount than the extra $\mathrm{H}_{2}$ emission $(7.48 \mathrm{~g} / \mathrm{d})$ observed for cows receiving the 3 -NOP treatment. This increase accounts for $23 \%$ of the calculated amount of unused $\mathrm{H}_{2}$ due to decreased $\mathrm{CH}_{4}$ production. When using a similar calculation with the data from Hristov et al. (2015) for the highest 3-NOP level, only $1.6 \%$ of theoretically unused $\mathrm{H}_{2}$ is accounted for. The much lower fraction accounted for in Hristov et al. (2015) compared with our results may be related to the measurement system, where rapidly occurring peaks in $\mathrm{H}_{2}$ emission are measured in the respiration chamber system, but may not be measured in the spotsampling GreenFeed system. This suggests that next to 3-NOP reducing $\mathrm{CH}_{4}$ emissions, the secondary effects of 3-NOP include a redirection of $\mathrm{H}_{2}$ to alternative $\mathrm{H}_{2}$ sinks, such as a redirected rumen fermentation profile toward propionate fermentation in particular (Haisan et al., 2014; Hristov et al., 2015).

The effects of lactation stage on gaseous exchange were relatively limited and if effects were detected, these could generally be linked to the observed changes in feed intake and lactation performance. The respiration quotient (RQ), for example, is lower or equal to 1.0 when only substrate oxidation occurs (Gerrits et al., 2015). However, de novo synthesis of FA and ruminal anaerobic fermentation of dietary carbohydrates can result in a RQ larger than 1.0 (Gerrits et al., 2015). The lower RQ at 27 DIM agrees with the lower proportions of short- and even-chain FA in milk (i.e., de novo synthesis of FA inhibited by body fat mobilization; see above) and the lower feed and nutrient intake (resulting in relatively less ruminal anaerobic fermentation) at 27 DIM. The increasing $\mathrm{H}_{2}$ intensity $(\mathrm{g} / \mathrm{kg}$ of FPCM and $\mathrm{g} / \mathrm{kg}$ of ECM) with advancing lactation stage is due to the unaffected $\mathrm{H}_{2}$ production in combination with the decreased yields of FPCM and ECM, according to the lactation curves.

\section{BW Change}

Treatment did not affect metabolic BW, but cows receiving the CON treatment gained less $\mathrm{BW}$ (on average $0.01 \%$ of $\mathrm{BW}$ ) than the cows receiving the 3 -NOP treatment (on average $0.90 \%$ of BW; Figure 3). This is contrary to Melgar et al. (2020), who reported no effect of 3-NOP on BW change. This difference in BW change in the current study might be related to the shift in the rumen fermentation profile. As mentioned before, others reported increased proportions of ruminal propionate upon feeding 3-NOP (Haisan et al., 2014, 2017). Propionate is classified as glucogenic and may result in increased insulin blood levels reducing mobilization of body reserves (van Knegsel et al., 2007b). Although not significant, there was a numerical difference in energy balance, with a negative energy balance for the CON treatment and positive for the 3-NOP treatment. Previously, in mid to late lactation cows, Haisan et al. (2017) did not observe differences in $\mathrm{BW}$ gain between $\mathrm{CON}$ and 3-NOP, whereas Haisan et al. (2014) and Hristov et al. (2015) observed a greater BW gain with 3-NOP compared with CON. In line with the latter 2 experiments, our results suggest a positive effect of 3 -NOP to prevent loss of BW in early lactation, but further research is required to confirm this. 


\section{CONCLUSIONS}

Feeding 3-nitrooxypropanol (51 $\mathrm{mg} / \mathrm{kg}$ of DM realized; $60 \mathrm{mg} / \mathrm{kg}$ of DM target) to dairy cattle in early lactation decreased $\mathrm{CH}_{4}$ emissions by an average of $15.8 \%$ (averaged over multiple units of $\mathrm{CH}_{4}$ emission). Differences in feed intake between the different stages of lactation appeared to affect the decrease in $\mathrm{CH}_{4}$ emissions upon feeding 3-NOP. Feeding 3-NOP increased $\mathrm{H}_{2}$ emissions by an average of 11-fold, where $\mathrm{H}_{2}$ emissions were 15 -fold greater at 27 DMI declining to 9-fold greater at 111 DIM, and did not affect DMI, milk yield and composition, or feed efficiency. The apparent total-tract digestibility of DM, OM, NDF, and GE was higher with 3-NOP. Energy and N balance were not affected by $3-\mathrm{NOP}$, but BW gain (in $\%$ of $\mathrm{BW}$ ) was greater with 3 -NOP compared with the CON treatment. It is concluded that feeding 3 -NOP is an effective strategy to decrease methane emissions in early lactation Holstein-Friesian cows with positive effects on apparent total-tract digestibility of nutrients.

\section{ACKNOWLEDGMENTS}

The staff of the research facility Carus (Wageningen, the Netherlands), in particular Marcel Heetkamp, Wim van Ommeren, Ries Verkerk, Teus Bleijenberg, and Bert Beukers, are gratefully acknowledged for their assistance during the implementation of the experiment, as are the laboratory staff of the Animal Nutrition Group (Wageningen, the Netherlands). The authors have not stated any conflicts of interest.

\section{REFERENCES}

Abrahamse, P. A., J. Dijkstra, B. Vlaeminck, and S. Tamminga. 2008. Frequent allocation of rotationally grazed dairy cows changes grazing behavior and improves productivity. J. Dairy Sci. 91:20332045. https://doi.org/10.3168/jds.2007-0579.

Allen, M. S. 2000. Effects of diet on short-term regulation of feed intake by lactating dairy cattle. J. Dairy Sci. 83:1598-1624. https:// doi.org/10.3168/jds.S0022-0302(00)75030-2.

Arunvipas, P., I. R. Dohoo, J. A. Vanleeuwen, and G. P. Keefe. 2003. The effect of non-nutritional factors on milk urea nitrogen levels in dairy cows. Prev. Vet. Med. 59:83-93. https://doi.org/10.1016/ S0167-5877(03)00061-8.

Auldist, M. J., B. J. Walsh, and N. A. Thomson. 1998. Seasonal and lactational influences on bovine milk composition in New Zealand. J. Dairy Res. 65:401-411. https://doi.org/10.1017/ S0022029998002970.

Bauman, D. E., and J. M. Griinari. 2003. Nutritional regulation of milk fat synthesis. Annu. Rev. Nutr. 23:203-227. https://doi.org/ 10.1146/annurev.nutr.23.011702.073408.

Beauchemin, K. A., M. Kreuzer, F. O'Mara, and T. A. McAllister. 2008. Nutritional management for enteric methane abatement: A review. Aust. J. Exp. Agric. 48:21-27. https://doi.org/10.1071/ EA07199.

Bergman, E. N. 1990. Energy contributions of volatile fatty acids from the gastrointestinal tract in various species. Physiol. Rev. 70:567590. https://doi.org/10.1152/physrev.1990.70.2.567.
Blaxter, K. L., and J. Czerkawski. 1966. Modifications of methane production of the sheep by supplementation of its diet. J. Sci. Food Agric. 17:417-421. https://doi.org/10.1002/jsfa.2740170907.

Carlsson, J., J. Bergstrom, and B. Pehrson. 1995. Variations with breed, age, season, yield, stage of lactation and herd in the concentration of urea in bulk milk and in individual cow's milk. Acta Vet. Scand. 36:245-254.

Christie, W. W. 1981. The composition, structure and function of lipids in the tissues of ruminant animals. Pages 95-191 in Lipid Metabolism in Ruminant Animals. W. W. Christie, ed. Pergamon Press, Oxford, UK.

Colucci, P. E., G. K. Macleod, W. L. Grovum, L. W. Cahill, and I. McMillan. 1989. Comparative digestion in sheep and cattle fed different forage to concentrate ratios at high and low intakes. J. Dairy Sci. 72:1774-1785. https://doi.org/10.3168/jds.S0022 -0302(89)79294-8.

CVB. 2012. Chemische Samenstellingen en Nutritionele Waarden van Voedermiddelen (in Dutch). CVB (Centraal Veevoederbureau), The Hague, the Netherlands.

Czerkawski, J. W. 1986. Transfer of metabolic hydrogen in the rumen. Pages 173-188 in An Introduction to Rumen Studies. Pergamon Press Inc., New York, NY.

Dijkstra, J., A. Bannink, J. France, E. Kebreab, and S. van Gastelen. 2018. Short communication: Antimethanogenic effects of 3-nitrooxypropanol depend on supplementation dose, dietary fiber content, and cattle type. J. Dairy Sci. 101:9041-9047. https://doi.org/ $10.3168 /$ jds.2018-14456.

Dijkstra, J., S. M. van Zijderveld, J. A. Apajalahti, A. Bannink, W. J. J. Gerrits, J. R. Newbold, H. B. Perdok, and H. Berends. 2011. Relationships between methane production and milk fatty acid profiles in dairy cattle. Anim. Feed Sci. Technol. 166-167:590-595. https://doi.org/10.1016/j.anifeedsci.2011.04.042.

Duin, E. C., T. Wagner, S. Shima, D. Prakash, B. Cronin, D. R. Yáñez-Ruiz, S. Duval, R. Rümbeli, R. T. Stemmler, R. K. Thauer, and M. Kindermann. 2016. Mode of action uncovered for the specific reduction of methane emissions from ruminants by the small molecule 3-nitrooxypropanol. Proc. Natl. Acad. Sci. USA 113:6172-6177. https://doi.org/10.1073/pnas.1600298113.

French, N., and J. J. Kennelly. 1990. Effects of feeding frequency on ruminal parameters, plasma insulin, milk yield and milk composition in Holstein cows. J. Dairy Sci. 73:1857-1863. https://doi.org/ 10.3168/jds.S0022-0302(90)78866-2.

Garnsworthy, P. C., L. L. Masson, A. L. Lock, and T. T. Mottram. 2006. Variation of milk citrate with stage of lactation and de novo fatty acid synthesis in dairy cows. J. Dairy Sci. 89:1604-1612. https://doi.org/10.3168/jds.S0022-0302(06)72227-5.

Garnsworthy, P. C., and J. H. Topps. 1982. The effect of body condition score at calving on their food intake and performance when given complete diets. Anim. Prod. 35:113-119.

Gerrits, W. J. J., J. J. G. C. van den Borne, and E. Labussière. 2015. Deriving heat production from gaseous exchange: Validity of the approach. Pages 19-34 in Indirect Calorimetry. Techniques, Computations and Applications. W. J. J. Gerrits and E. Labussière, ed. Wageningen Academic Publishers, Wageningen, the Netherlands.

Grossman, M., and W. J. Koops. 1988. Multiphasic analysis of lactation curves in dairy cattle. J. Dairy Sci. 71:1598-1608. https://doi .org/10.3168/jds.S0022-0302(88)79723-4.

Haisan, J., Y. Sun, L. L. Guan, K. A. Beauchemin, A. Iwaasa, S. Duval, D. R. Barreda, and M. Oba. 2014. The effects of feeding 3-nitrooxypropanol on methane emissions and productivity of Holstein cows in mid lactation. J. Dairy Sci. 97:3110-3119. https://doi.org/ 10.3168/jds.2013-7834.

Haisan, J. Y., Y. Sun, L. Guan, K. A. Beauchemin, A. Iwaasa, S. Duval, M. Kindermann, D. R. Barreda, and M. Oba. 2017. The effects of feeding 3-nitrooxypropanol at two doses on milk production, rumen fermentation, plasma metabolites, nutrient digestibility, and methane emissions in lactating Holstein cows. Anim. Prod. Sci. 57:282-289. https://doi.org/10.1071/AN15219.

Hartnell, G. F., and L. D. Satter. 1979. Determination of rumen fill, retention time and ruminal turnover rates of ingesta at different 
stages of lactation in dairy cows. J. Anim. Sci. 48:381-392. https: //doi.org/10.2527/jas1979.482381x.

Hatew, B., S. C. Podesta, H. Van Laar, W. F. Pellikaan, J. L. Ellis, J. Dijkstra, and A. Bannink. 2015. Effects of dietary starch content and rate of fermentation on methane production in lactating dairy cows. J. Dairy Sci. 98:486-499. https://doi.org/10.3168/jds.2014 $-8427$.

Heetkamp, M. J. W., S. J. J. Alferink, T. Zandstra, P. Hendriks, H. van den Brand, and W. J. J. Gerrits. 2015. Design of climate respiration chambers, adjustable to the metabolic mass of subjects. Pages 35-56 in Indirect Calorimetry. Techniques, Computations and Applications. W. J. J. Gerrits and E. Labussière, ed. Wageningen Academic Publishers, Wageningen, the Netherlands.

Hristov, A. N., J. Oh, J. L. Firkins, J. Dijkstra, E. Kebreab, G. Waghorn, H. P. S. Makkar, A. T. Adesogan, W. Yang, C. Lee, P. J. Gerber, B. Henderson, and J. M. Tricarico. 2013. Mitigation of methane and nitrous oxide emissions from animal operations: I. A review of enteric methane mitigation options. J. Anim. Sci. 91:5045-5069. https://doi.org/10.2527/jas.2013-6583.

Hristov, A. N., J. Oh, F. Giallongo, T. W. Frederick, M. T. Harper, H. L. Weeks, A. F. Branco, P. J. Moate, M. H. Deighton, S. R. O. Williams, M. Kindermann, and S. Duval. 2015. An inhibitor persistently decreased enteric methane emission from dairy cows with no negative effect on milk production. Proc. Natl. Acad. Sci. USA 112:10663-10668. https://doi.org/10.1073/pnas.1504124112.

International Organization for Standardization. 1998. ISO 9831:1998. Animal feedstuffs, animal products, and feces or urine-Determination of gross caloric values-Bomb calorimeter method. International Organization for Standardization, Geneva, Switzerland.

International Organization for Standardization. 2005. ISO 5983:2005. Animal feeding stuffs. Determination of nitrogen content and calculation of crude protein content-Part 1: Kjeldahl method. International Standards Organization, Geneva, Switzerland.

International Organization for Standardization. 2013. ISO 9622:2013. Milk and liquid milk products. Guidelines for the application of mid-infrared spectrometry. International Standards Organization, Geneva, Switzerland.

Janssen, P. H. 2010. Influence of hydrogen on rumen methane formation and fermentation balances through microbial growth kinetics and fermentation thermodynamics. Anim. Feed Sci. Technol. 160:1-22. https://doi.org/10.1016/j.anifeedsci.2010.07.002.

Jílek, F., D. Řehák, J. Volek, M. Štípková, E. Němcová, M. Fiedlerová, R. Rajmon, and D. Švestková. 2006. Effect of herd, parity, stage of lactation and milk yield on urea concentration in milk. Czech J. Anim. Sci. 51:510-517. https://doi.org/10.17221/3971-CJAS.

Kay, J. K., W. J. Weber, C. E. Moore, D. E. Bauman, L. B. Hansen, H. Chester-Jones, B. A. Crooker, and L. H. Baumgard. 2005. Effects of week of lactation and generic selection for milk yield on milk fatty acid composition in Holstein cows. J. Dairy Sci. 88:3886-3893. https://doi.org/10.3168/jds.S0022-0302(05)73074-5.

Kim, S.-H., C. Lee, H. A. Pechtl, J. M. Hettick, M. R. Campler, M. D. Pairis-Garcia, K. A. Beauchemin, P. Celi, and S. M. Duval. 2019. Effects of 3-nitrooxypropanol on enteric methane production, rumen fermentation, and feeding behavior in beef cattle fed a high forage or high grain diet. J. Anim. Sci. 97:2687-2699. https://doi .org/10.1093/jas/skz140.

Klop, G., B. Hatew, A. Bannink, and J. Dijkstra. 2016. Feeding nitrate and docosahexaenoic acid affects enteric methane production and milk fatty acid composition in lactating dairy cows. J. Dairy Sci. 99:1161-1172. https://doi.org/10.3168/jds.2015-10214.

Lopes, J. C., L. F. de Matos, M. T. Harper, F. Giallongo, J. Oh, D. Gruen, S. Ono, M. Kindermann, S. Duval, and A. N. Hristov. 2016. Effect of 3-nitrooxypropanol on methane and hydrogen emissions, methane isotopic signature, and ruminal fermentation in dairy cows. J. Dairy Sci. 99:5335-5344. https://doi.org/10.3168/jds.2015 -10832 .

Maltz, E., and N. Silanikove. 1996. Kidney function and nitrogen balance of high yielding dairy cows at the onset of lactation. J. Dairy Sci. 79:1621-1626. https://doi.org/10.3168/jds.S0022 $-0302(96) 76525-6$.
Martin, C., D. P. Morgavi, and M. Doreau. 2010. Methane mitigation in ruminants: From microbe to the farm scale. Animal 4:351-365. https://doi.org/10.1017/S1751731109990620.

McAllister, T. A., and C. J. Newbold. 2008. Redirecting rumen fermentation to reduce methanogenesis. Aust. J. Exp. Agric. 48:7-13. https://doi.org/10.1071/EA07218.

Melgar, A., M. T. Harper, J. Oh, F. Giallongo, M. E. Young, T. L. Ott, S. Duval, and A. N. Hristov. 2020. Effects of 3-nitrooxypropanol on rumen fermentation, lactational performance, and resumption of ovarian cyclicity in dairy cows. J. Dairy Sci. 103:410-432. https://doi.org/10.3168/jds.2019-17085.

Moore, J. H., and W. W. Christie. 1981. Lipid metabolism in the mammary gland of ruminant animals. Pages $227-277$ in Lipid Metabolism in Ruminant Animals. W. W. Christie, ed. Pergamon Press, Oxford, UK.

National Research Council (NRC). 2001. Nutrient Requirements of Dairy Cattle. 7th ed. National Academy Press, Washington, DC.

Nichols, K., A. Bannink, S. Pacheco, H. J. van Valenberg, J. Dijkstra, and H. van Laar. 2018. Feed and nitrogen efficiency are affected differently but milk lactose production is stimulated equally when isoenergetic protein and fat is supplemented in lactating dairy cow diets. J. Dairy Sci. 101:7857-7870. https://doi.org/10.3168/jds .2017-14276.

Palmquist, D. L., A. Denise Beaulieu, and D. M. Barbano . 1993. Feed and animal factors influencing milk fat composition. J. Dairy Sci. 76:1753-1771. https://doi.org/10.3168/jds.S0022-0302(93)77508 $-6$.

Pereira, S. L., A. E. Leonard, and P. Mukerji. 2003. Recent advances in the study of fatty acid desaturases from animals and lower eukaryotes. Prostaglandins Leukot. Essent. Fatty Acids 68:97-106. https://doi.org/10.1016/S0952-3278(02)00259-4.

Prakash, D., Y. Wu, S. J. Suh, and E. C. Duin. 2014. Elucidating the process of activation of methyl-coenzyme M reductase. J. Bacteriol. 196:2491-2498. https://doi.org/10.1128/JB.01658-14.

Reynolds, C. K., D. J. Humphries, P. Kirton, M. Kindermann, S. Duval, and W. Steinberg. 2014. Effects of 3-nitrooxypropanol on methane emission, digestion, and energy and nitrogen balance of lactating dairy cows. J. Dairy Sci. 97:3777-3789. https://doi.org/ 10.3168/jds.2013-7397.

Shalit, U., E. Maltz, N. Silanikove, and A. Berman. 1991. Water, sodium, potassium and chlorine metabolism of dairy cows at the onset of lactation in hot weather. J. Dairy Sci. 74:1874-1883. https://doi .org/10.3168/jds.S0022-0302(91)78353-7.

Spek, J. W., J. Dijkstra, G. van Duinkerken, and A. Bannink. 2013. A review of factors influencing milk urea concentration and its relationship with urinary urea excretion in lactating dairy cattle. J. Agric. Sci. 151:407-423. https://doi.org/10.1017/ S0021859612000561.

Stoop, W. M., H. Bovenhuis, J. M. L. Heck, and J. A. M. van Arendonk. 2009. Effect of lactation stage and energy status on milk fat composition of Holstein-Friesian cows. J. Dairy Sci. 92:1469-1478. https://doi.org/10.3168/jds.2008-1468.

Tamminga, S., P. A. Luteijn, and R. G. M. Meijer. 1997. Changes in composition and energy content of liveweight loss in dairy cows with time after parturition. Livest. Prod. Sci. 52:31-38. https:// doi.org/10.1016/S0301-6226(97)00115-2.

Tyrrell, H. F., and J. T. Reid. 1965. Prediction of the energy value of cow's milk. J. Dairy Sci. 48:1215-1223. https://doi.org/10.3168/ jds.S0022-0302(65)88430-2.

Van Duinkerken, G., M. C. Blok, A. Bannink, J. W. Cone, J. Dijkstra, A. M. van Vuuren, and S. Tamminga. 2011. Update of the Dutch protein evaluation system for ruminants: The DVE/ OEB2010 system. J. Agric. Sci. 149:351-367. https://doi.org/10 .1017/S0021859610000912.

Van Es, A. J. H. 1978. Feed evaluation for ruminants. I. The systems in use from May 1977-onwards in the Netherlands. Livest. Prod. Sci. 5:331-345. https://doi.org/10.1016/0301-6226(78)90029-5.

van Gastelen, S., E. C. Antunes-Fernandes, K. A. Hettinga, G. Klop, S. J. J. Alferink, W. H. Hendriks, and J. Dijkstra. 2015. Enteric methane production, rumen volatile fatty acid concentrations, and 
milk fatty acid composition in lactating Holstein-Friesian cows fed grass silage- or corn silage-based diets. J. Dairy Sci. 98:1915-1927. https://doi.org/10.3168/jds.2014-8552.

van Gastelen, S., and J. Dijkstra. 2016. Prediction of methane emission from lactating dairy cows using milk fatty acids and midinfrared spectroscopy. J. Sci. Food Agric. 96:3963-3968. https://doi .org/10.1002/jsfa.7718.

van Gastelen, S., M. H. P. W. Visker, J. E. Edwards, E. C. AntunesFernandes, K. A. Hettinga, S. J. J. Alferink, W. H. Hendriks, H. Bovenhuis, H. Smidt, and J. Dijkstra. 2017. Linseed oil and DGAT1 K232A polymorphism: Effects on methane emission, energy and nitrogen metabolism, lactation performance, ruminal fermentation, and rumen microbial composition of Holstein-Friesian cows. J. Dairy Sci. 100:8939-8957. https://doi.org/10.3168/jds 2016-12367.

van Knegsel, A. T. M., H. van den Brand, J. Dijkstra, W. M. van Straalen, M. J. W. Heetkamp, S. Tamminga, and B. Kemp. 2007a. Dietary energy source in dairy cows in early lactation: energy partitioning and milk composition. J. Dairy Sci. 90:1467-1476. https: //doi.org/10.3168/jds.S0022-0302(07)71632-6.

van Knegsel, A. T. M., H. van den Brand, E. A. M. Graat, J. Dijkstra, R. Jorritsma, E. Decuypere, S. Tamminga, and B. Kemp. 2007b. Dietary energy source in dairy cows in early lactation: metabolites and metabolic hormones. J. Dairy Sci. 90:1477-1485. https://doi .org/10.3168/jds.S0022-0302(07)71633-8.

van Lingen, H. J., C. M. Plugge, J. G. Fadel, E. Kebreab, A. Bannink, and J. Dijkstra. 2016. Thermodynamic driving force of hydrogen on rumen microbial metabolism: a theoretical investigation. PLoS One 11:e0161362. https://doi.org/10.1371/journal.pone.0161362. van Zijderveld, S. M., W. J. J. Gerrits, J. Dijkstra, J. R. Newbold, R. B. A. Hulshof, and H. B. Perdok. 2011. Persistency of methane mitigation by dietary nitrate supplementation in dairy cows. J. Dairy Sci. 94:4028-4038. https://doi.org/10.3168/jds.2011-4236.

Veerkamp, R. F., B. Beerda, and T. Van der Lende. 2003. Effects of genetic selection for milk yield on energy balance, levels of hormones, and metabolites in lactating cattle, and possible links to reduced fertility. Livest. Prod. Sci. 83:257-275. https://doi.org/10 .1016/S0301-6226(03)00108-8.

Vlaeminck, B., V. Fievez, A. R. J. Cabrita, A. J. M. Fonseca, and R. J. Dewhurst. 2006. Factors affecting odd- and branched-chain fatty acids in milk: A review. Anim. Feed Sci. Technol. 131:389-417. https://doi.org/10.1016/j.anifeedsci.2006.06.017.

Zhou, Y., A. E. Dorchak, and S. W. Ragsdale. 2013. In vivo activation of methyl-coenzyme M reductase by carbon monoxide. Front. Microbiol. 4:69. https://doi.org/10.3389/fmicb.2013.00069.

Zom, R. L. G., G. André, and A. M. van Vuuren. 2012. Development of a model for the prediction of feed intake by dairy cows: 1 . Prediction of feed intake. Livest. Sci. 143:43-57. https://doi.org/10 .1016/j.livsci.2011.08.014.

\section{ORCIDS}

Sanne van Gastelen (1) https://orcid.org/0000-0003-4547-8449

Jan Dijkstra (은 https://orcid.org/0000-0003-3728-6885

Jeroen M. L. Heck @ https://orcid.org/0000-0001-6772-2495 